University of Nebraska - Lincoln

DigitalCommons@University of Nebraska - Lincoln

$12-2003$

\title{
Chemistry of Cirsium and Carduus: A role in ecological risk assessment for biological control of weeds?
}

Ingrid E. Jordon-Thaden

University of Nebraska - Lincoln

Svata M. Louda

University of Nebraska - Lincoln, slouda1@unl.edu

Part of the Life Sciences Commons

Jordon-Thaden, Ingrid E. and Louda, Svata M., "Chemistry of Cirsium and Carduus: A role in ecological risk assessment for biological control of weeds?" (2003). Faculty Publications in the Biological Sciences. 85. https://digitalcommons.unl.edu/bioscifacpub/85

This Article is brought to you for free and open access by the Papers in the Biological Sciences at DigitalCommons@University of Nebraska - Lincoln. It has been accepted for inclusion in Faculty Publications in the Biological Sciences by an authorized administrator of DigitalCommons@University of Nebraska - Lincoln. 
Published in Biochemical Systematics and Ecology 31:12 (December 2003), pp. 1353-1396; doi: 10.1016/S0305-1978(03)00130-3 Copyright ( 2003 Elsevier Ltd. Used by permission. http://www.elsevier.com/locate/biochemsyseco

Submitted September 26, 2002; accepted March 26, 2003; published online July 18, 2003.

\title{
Chemistry of Cirsium and Carduus: A role in ecological risk assessment for biological control of weeds?
}

\author{
Ingrid E. Jordon-Thaden and Svata M. Louda \\ School of Biological Sciences, University of Nebraska-Lincoln, \\ Lincoln, NE 68588-0118, USA
}

Corresponding author - S. M. Louda, tel 402 472-2763, fax 402 472-2083, email slouda@unl.edu

\begin{abstract}
Prediction of host plant range and ecological impact of exotic phytophagous insects, such as insects for classical biological control of weeds, represents a major challenge. Recently, the flowerhead weevil (Rhinocyllus conicus Fröl.), introduced from Europe into North America to control exotic thistles (Carduus spp.), has become invasive. It feeds heavily on some, but not all species of native North American thistles (Cirsium spp.). We hypothesized that such non-target use among native plants could be better predicted by knowledge of characteristic chemical profiles of secondary compounds to supplement the results of host specificity testing. To evaluate this hypothesis, we reviewed the literature on the chemistry of Cirsium and Carduus thistles. We asked what compounds are known to be present, what is known about their biological activity, and whether such information on chemical profiles would have better predicted realized host range and ecological effects of $R$. conicus in North America. We found an extensive, but incomplete literature on the chemistry of true thistles. Two main patterns emerged. First, consistent chemical similarities and interesting differences occur among species of thistles. Second, variation occurs in biologically active groups of characteristic compounds, specifically flavonoids, sterols, alkaloids and phenolic acids, that are known to influence host plant acceptance, selection, and feeding by phytophagous insects. Surprisingly, sesquiterpene lactones, which are characteristic in closely related Asteraceae, have not been extensively reported for Cirsium or Carduus. The minimal evidence on sesquiterpene lactones may reflect extraction methods vs. true absence. In summary, our review suggests further research on thistle chemistry in insect feeding is warranted. Also, since the exotic Canada thistle (Cirsium arvense) is an invasive thistle of current concern in North America, such research on mechanisms underlying host range expansion by exotic insects would be useful.
\end{abstract}

Keywords: Carduus, chemical mediation, Cirsium, flavonoids, host range expansion, insect host preference, insect herbivory, secondary metabolites, sterols 


\section{Introduction}

Invasive exotic species, such as Eurasian thistles, present a major threat to sustained productivity and biodiversity in the United States (Vitousek et al., 1997; Simberloff, 1997; National Invasive Species Council, 2001; Pimentel et al., 2000). Consequently, such exotic weeds often are targeted for classical biological control, i.e. the importation, release, and redistribution of exotic insects from the region of the weed's origin to limit the plant's invasiveness (DeBach and Rosen, 1991; OTA, 1995; Delfosse, 2000). However, the release of exotic insects entails a risk to native plants and communities (Howarth, 1991; Simberloff and Stiling, 1996; Louda et al., 1997, 1998; Stiling and Simberloff, 1999). Prediction of both the risk and the ecological impact of exotic insects poses a critical challenge (Louda, 1999a; Strong and Pemberton, 2000; Louda et al., 2003a, 2003b).

The extraordinary diversity of plant secondary metabolites (see, for example, Rosenthal and Berenbaum, 1991 \& Walton and Brown, 1999), combined with the known influence of some of these chemicals upon insects (e.g. Carde and Bell, 1995), suggests that comparative chemistry may contribute to improving prediction of the host use and impact of introduced herbivorous insects. However, the role of chemical composition and variation in predicting the interactions between insect biological control agents and their targeted, exotic host plants relative to potential non-targeted, less preferred (secondary) native host species has yet to be explored.

In this study, we reviewed the literature on the reported chemical profiles in the two main genera of true thistles (Cirsium, Carduus) in order to determine whether such information would improve the likelihood of predicting relative host plant use and non-target effects. In the specific case of the Eurasian biological control weevil (Rhinocyllus conicus Frölich), introduced for exotic thistle control, about one-third of the native North American thistle species are now reported as host plants (Goeden and Ricker, 1986a, 1986b, 1987a, 1987b; Turner et al., 1987; Louda et al., 1997, 1998). Populations of some species are being severely impacted (Louda et al., 1997, 1998; Louda, 1999a; Louda and Arnett, 2000). Thus, an additional aim of this review was to collate the information that may aid in the further development of screening protocols in similar cases, such as the biological control efforts now targeting the invasive Eurasian Cirsium arvense (Canada thistle) in North America.

It seems paradoxical that despite 50 years of studies showing chemical variation among plants as a significant factor in the preference and performance of insects on plants (e.g. Dethier, 1947; Ehrlich and Raven, 1964; Singer, 1971; Futuyma, 1983; Price, 1984; Spencer, 1988; Roitberg and Isman, 1992; Rosenthal and Berenbaum, 1991; Bernays and Chapman, 1994; Carde and Bell, 1995), there is still little evidence on the role of chemical variation in host range expansion. Un- 
answered questions include the degree to which chemical profile matters (Courtney and Kibota, 1990), the amount of chemical differentiation necessary to retard range expansion, and the precision of laboratory bioassays of insect preference in prediction of ecological effects on secondary hosts by a biological control insect (Arnett and Louda, 2002; Louda et al., 2003a, 2003b).

Phylogenetic relationships, geographic distribution, and host chemistry have been hypothesized to be determinants of the evolution and ecology of insect host preference, host range, and host shifts (Becerra, 1997). Becerra and Venable (1999) recently argued that host chemistry was the most significant of these factors. They found that host shifts by Blepharida spp. beetles were best explained by chemical similarities among host plants, independent of either molecular phylogeny or geographic distribution (Becerra, 1997; Becerra and Venable, 1999). Such findings suggest the hypothesis that knowledge of chemical profiles among potential host plant species could improve the prediction of the ultimate host range and, so, the assessment of the potential for significant non-target effects among native plants that are identified as secondary hosts in host specificity testing of insects for weed biocontrol. To date, host chemistry has not been evaluated explicitly in such ecological risk assessments of host range for biocontrol insects.

The specific case history that stimulated our interest in this hypothesis is the current interaction of the Eurasian flower head weevil, Rhinocyllus conicus, with non-targeted native North American Cirsium spp. This weevil, which was introduced to control naturalized exotic Carduus spp. such as musk thistle (Carduus nutans), uses the flower heads of more than $33 \%$ of the $90^{+}$native North American thistles (Cirsium spp.) examined thus far (Goeden and Ricker, 1986a, 1986b, 1987a, 1987b; Turner et al., 1987; Palmisano and Fox, 1997; Louda et al., 1997, 1998; Louda, 1998, 1999b; Herr, 2000). However, preference and relative use vary among thistle species. Reductions in seed production by $R$. conicus are greater for some species than others (Zwölfer and Harris, 1984; Turner et al., 1987; Louda et al., 1997, 1998; Louda, 1998, 1999b; Herr, 2000, Louda and Arnett, 2000; Gassmann and Louda, 2001). The weevil is severely reducing seed production in half of the native thistle species studied intensively in natural areas and national parks in the Great Plains and Rocky Mountains (Louda et al., 1997, 1998, 1999a). The population density of Platte thistle (Cirsium canescens Nutt.), the most intensively studied native species (Louda and Potvin, 1995), has declined significantly since $R$. conicus invaded the native prairie sites, with less evidence of feeding impact on the numbers of the co-occurring wavyleaf thistle, C. undulatum (Louda, 1998, 1999a; Louda and Arnett, 2000).

Better understanding of the potential role of chemical mediation in the varied non-target effects observed has important implications, both for our basic understanding of host range expansion and for the evaluation of insects for biological control of weeds. If evolution of chemical mediation of host range and preferences is important (Becerra and Venable, 1999), then three conditions must be met. These are: (1) insect preference among available host plant species must exist; (2) characteristic chemical profiles must vary; and (3) insect behavioral responses must reflect that chemical variation. We found support for each of these conditions in the literature. 
First, the existence of insect preference hierarchies is well substantiated, including for R. conicus (Zwölfer and Harris, 1984). The voluminous literature demonstrates the existence of consistent host plant preferences of phytophagous insects among plant species (see, for example, Spencer, 1988 \& Carde and Bell, 1995), including for R. conicus in Europe (Zwölfer, 1965; Zwölfer and Harris, 1984; Gassmann and Louda, 2001) and in North America (e.g. Turner et al., 1987; Louda and Arnett, 2000; Arnett and Louda, 2002).

Second, abundant evidence documents both differences and similarities in secondary plant metabolites among closely related plants (e.g. Wagner, 1977; Hegnauer, 1989; Harborne, 1990, 1991; Rosenthal and Berenbaum, 1991). No recent study, however, has compiled the evidence available on chemical profiles of true thistles. Our preliminary observations suggested that variation in characteristic profiles of biologically active compounds of Carduus and Cirsium could be important in the $R$. conicus case. For example, some of the flavonoids, such as apigenin, overlap between the preferred coevolved weed, Carduus nutans, and newly acquired native North American host plants, such as Cirsium canescens and C. undulatum. Yet, other flavonoids, such as chrysoeriol vs. luteolin, differentiate exotic Carduus spp. from native prairie Cirsium spp. (see below). These observations suggested a new synthesis of the information available on chemical profiles of thistles is needed to assess the hypothesis of chemical mediation in non-target thistle plant use by $R$. conicus in North America.

Third, a large body of evidence shows that insect acceptance, preference, and proximate host choice often are related to chemical profile (e.g. Spencer, 1988; Bernays and Chapman, 1994; Carde and Bell, 1995; Becerra and Venable, 1999; Simmonds, 2001). However, the potential contribution of overlap and non-overlap in chemical profiles to host preference and observed variation in feeding and oviposition by thistle-feeding species, such as $R$. conicus, is unknown.

Thus, four fundamental questions guided our review. First, what is known about the chemical profiles of two of the main genera of true thistles (Cirsium and Carduus: Family Asteraceae, Tribe Carduinae, Subtribe Carduineae) that are respectively native and non-native in North America? Second, what is the evidence that these plant secondary metabolites are biologically active, providing a potential mechanism for mediation of differential feeding and oviposition by thistleadapted insects among potentially acceptable hosts in the field? Third, to what extent would knowledge of the chemical profile and biological activity of Cirsium and Carduus have enhanced our ability to predict whether rare North American Cirsium spp. were vulnerable to potential ecological impacts by the alien Eurasian biological control insect, R. conicus? Finally, could similar information be used in contemporary efforts for biological control in management of other invasive Eurasian species, such as Canada thistle (Cirsium arvense)?

In this review we follow Harborne (1999) and define secondary metabolites as substances that do not appear to have primary metabolic functions (photosynthesis, respiration, and carbon fixation) and which vary in their distribution in the plant kingdom. For a compound to be classified as biologically active, there must be evidence that it can be taken up by an organism and that this uptake has some effect (Berenbaum, 1995). Documented functions of some secondary metabo- 
lites include: UV protection, defense against pathogens, and hormonal regulation (see Rosenthal and Berenbaum, 1991; Harborne et al., 1999; Walton and Brown, 1999). Mixtures of compounds also can act synergistically to affect insect behavior (e.g. Berenbaum and Zangerl, 1988; Macedo and Langenheim, 1989; Desrochers and Bohm, 1993; Espinosa-Garcia and Langenheim, 1991; Cates, 1996; Harborne, 1999).

\section{Chemistry and biological activity of compounds from Cirsium and Carduus}

We found information on secondary chemistry from 92 species of Cirsium and 12 species of Carduus. The compounds reported include: flavonoids, sterols and triterpenes, alkaloids, polyacetylenes, acetylenes and hydrocarbons, sesquiterpene lactones, phenolic acids, lignans, and a few other compounds (Figure 1). These<smiles>CCc1c(O)c(CC)c2oc(-c3ccc(O)cc3)cc(=O)c2c1O</smiles>

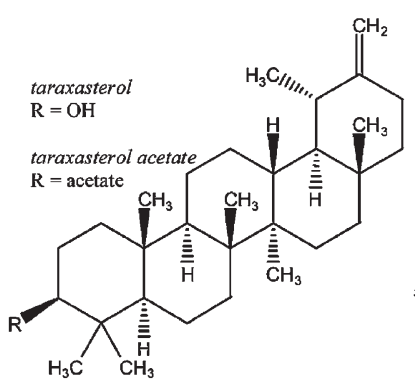

Triterpenes<smiles>CC1(C)CCC2(CO)CC[C@@]3(C)C(=CC[C@H]4[C@]5(C)CC[C@H](OC(C)(C)C)C(C)(C)[C@@]5(C)CC[C@]43C)C2C1</smiles>

Alkaloids
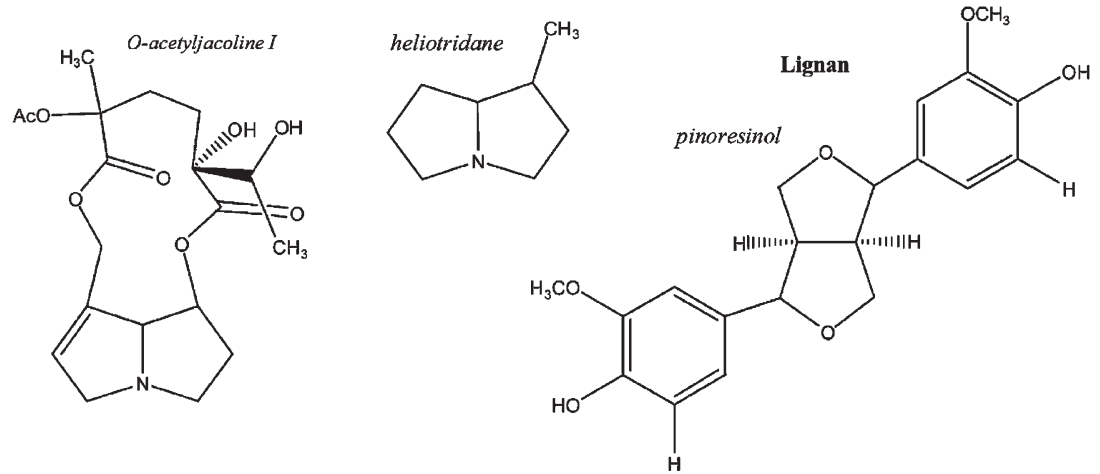

Figure 1. Selected compounds reported to show insect bioactivity. 
data are reviewed by chemical family, first for flavonoids as the group for which the most data exist (Tables $1 \& 2$ ), and then for the other compounds reported (Tables $3 \& 4$ ).

\subsection{Flavonoids}

\subsubsection{Chemistry}

The best-known group of secondary metabolites in Cirsium and Carduus are flavonoids (Tables 1 \& 2). However, in a recent review of flavonoids and their importance in feeding and oviposition of insects, Simmonds (2001) pointed out that, in spite of extensive research on flavonoids, little information exists on their chemical ecology. Most of the research on flavonoids has focused on chemotaxonomic, rather than ecological, questions, including for the Asteraceae (Bohm, 1998). By 1994, the total number of flavonoids known was over 4000 (Harborne, 1999). Derived from the acetate/malonate pathway for the A ring and the shikimate pathway for the B and C rings, these compounds can be found in almost all the plants' organs, including stems, leaves, and flowers (Strack, 1997). Most flavonoids consist of three six-carbon rings, with one containing a carbonyl group and each ring having different alcohol, methyl ether, or glycosidic (sugar) substituents. The different moieties affect the activity of the flavonoid (Hedin and Waage, 1986; ElLakany et al., 1997; below). Since Cirsium and Carduus spp. flavonoids differ widely in their sugars (Tables $1 \& 2$ ), the variation represents a potential mechanism for host recognition and differences in host preference.

\subsubsection{Biological activity}

The reported biological activity of flavonoids toward insects ranges from feeding deterrents for generalized phytophagous insects (e.g. Hedin and Waage, 1986; Harborne, 1990) to feeding stimulants and oviposition inducers, such as luteolin, for more specialized insects (e.g. Feeny et al., 1988; Harborne, 1991; Haribal and Renwick, 1996). In a review of the role of flavonoids in insect-plant interactions, Simmonds (2001) found clear evidence flavonoids can affect insect feeding and oviposition, and she documented variability in flavonoid activity: among insect species, stages of insect maturity, and extract concentrations. For example, Feeny et al. (1988) found luteolin 7-O-(6"-O-malonyl)- $\beta$-D-glucoside, in combination with trans-chlorogenic acid from wild carrot (Daucus carota), stimulated oviposition by the black swallowtail butterfly (Papilio polyxenes). However, individually the compounds had no effect. Also, Zielske et al. (1972) found that a derivative of luteolin, 7- $\alpha$-L-rhamnosyl-6-methoxyluteolin, from alligator weed (Alternanthera phylloxeroides) was at least partially responsible for the feeding preference of Agasicles spp. leaf beetles. Quercetin, a common flavonoid extracted from cotton (Gossypium hirsutum) and also found in Cirsium and Carduus spp., stimulated feeding by the boll weevil, Anthonomus grandis (Hedin et al., 1968). Haribal and Renwick (1996) found that, out of six glycosidic quercetin compounds in Asclepias curassavica, only two were active as oviposition stimulants for the monarch butterfly, Danaus plexippus. Interestingly, the only difference among the six compounds was the constituent sugar (Haribal and 


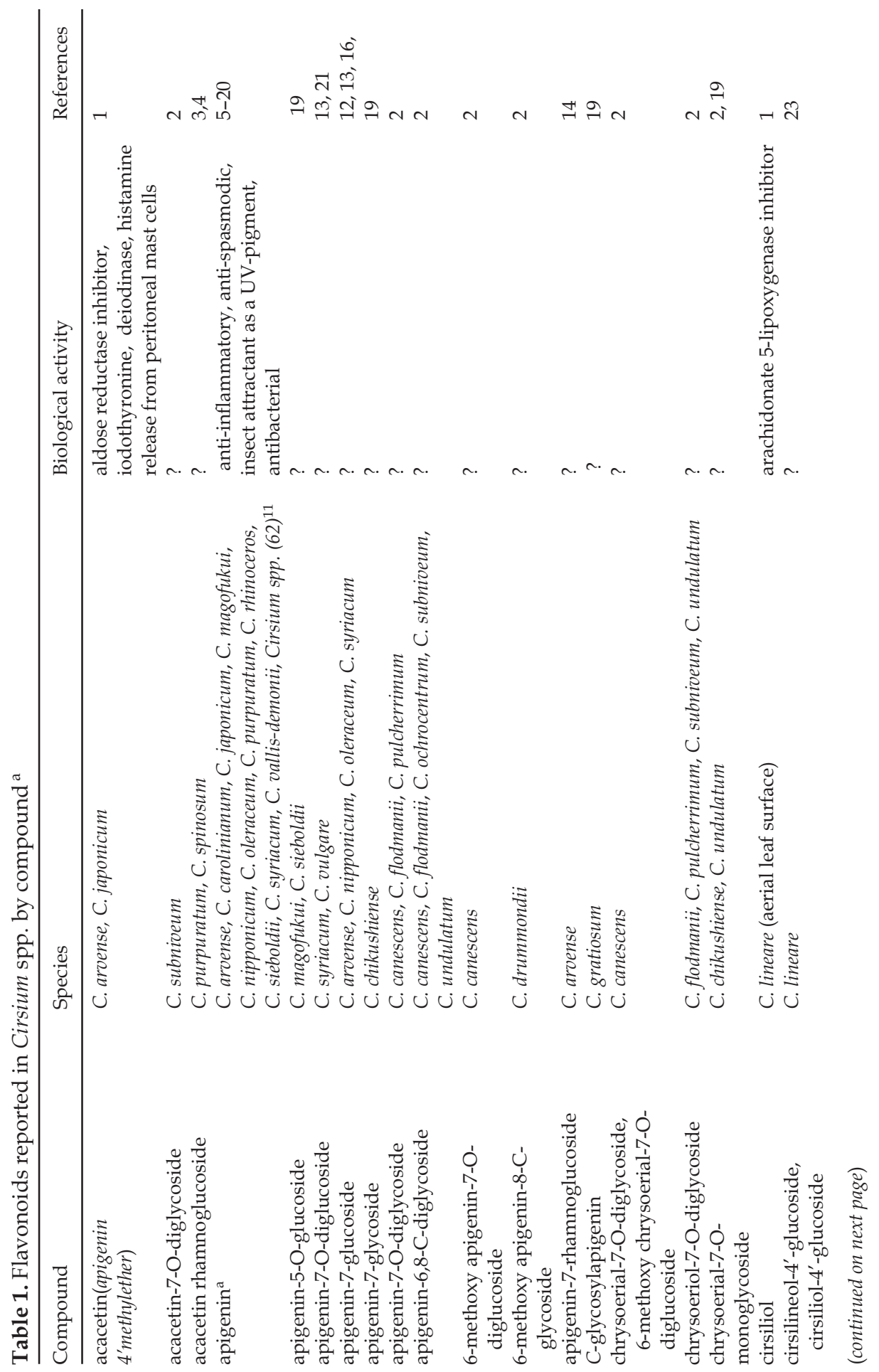




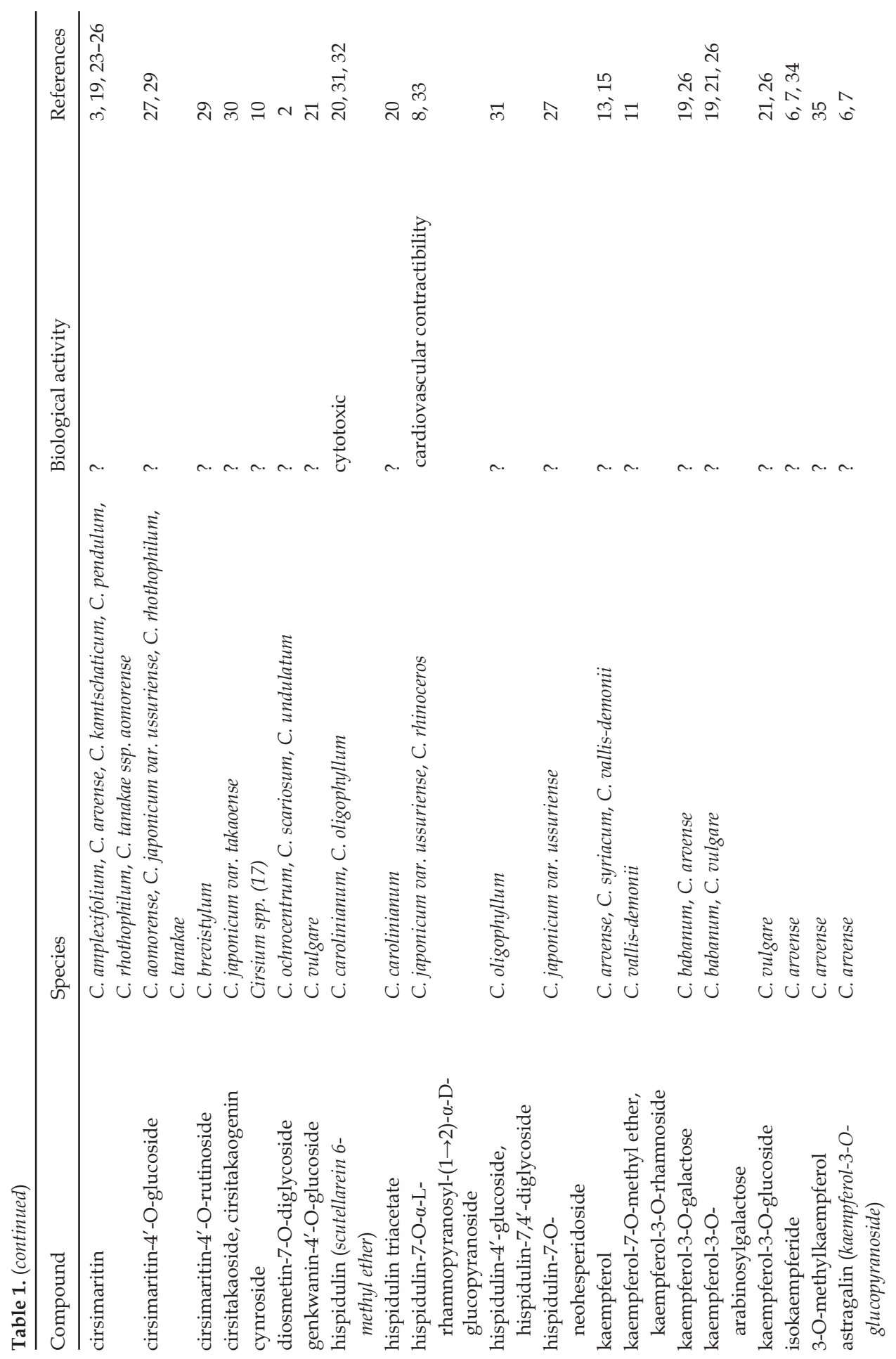




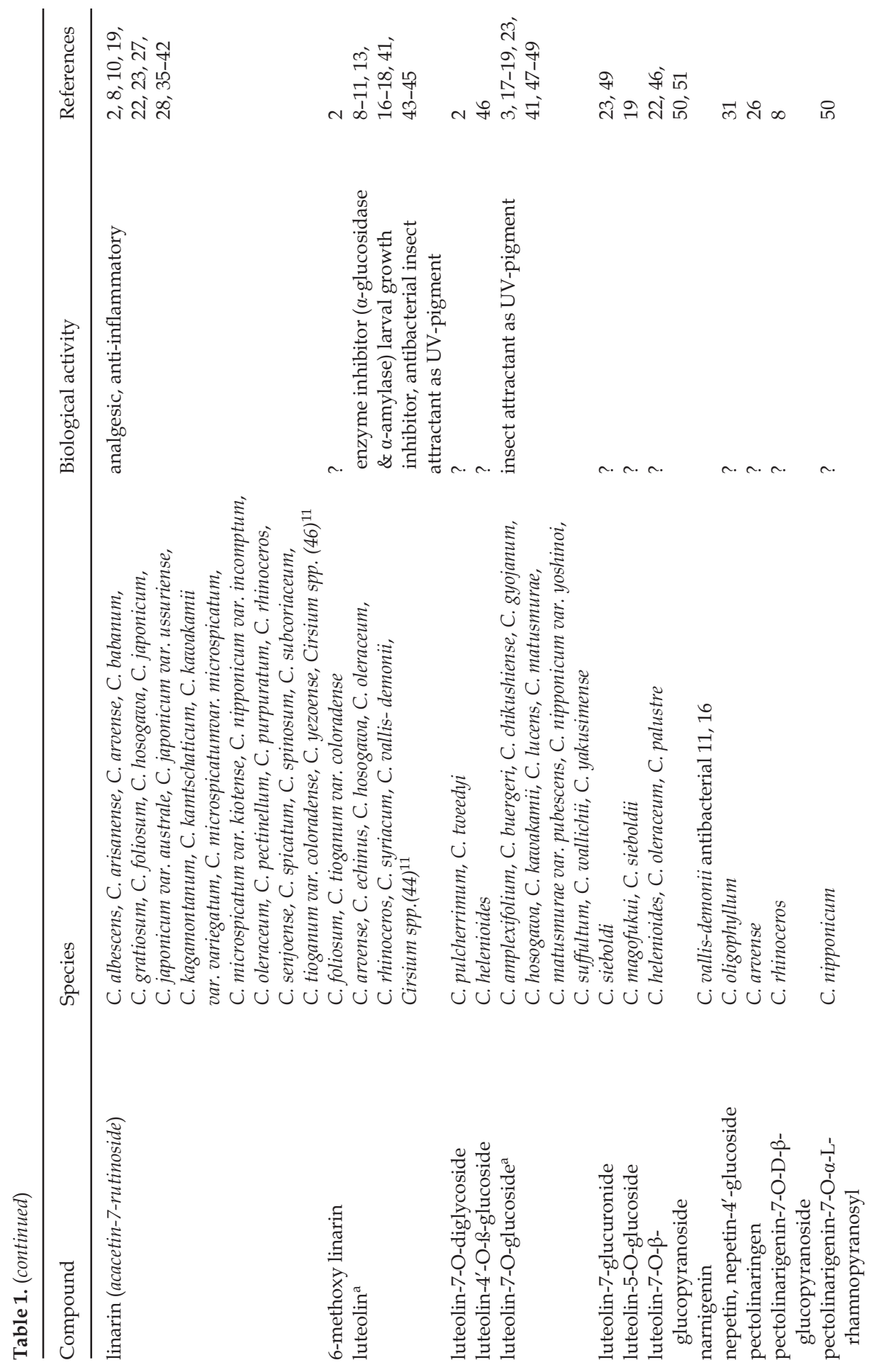




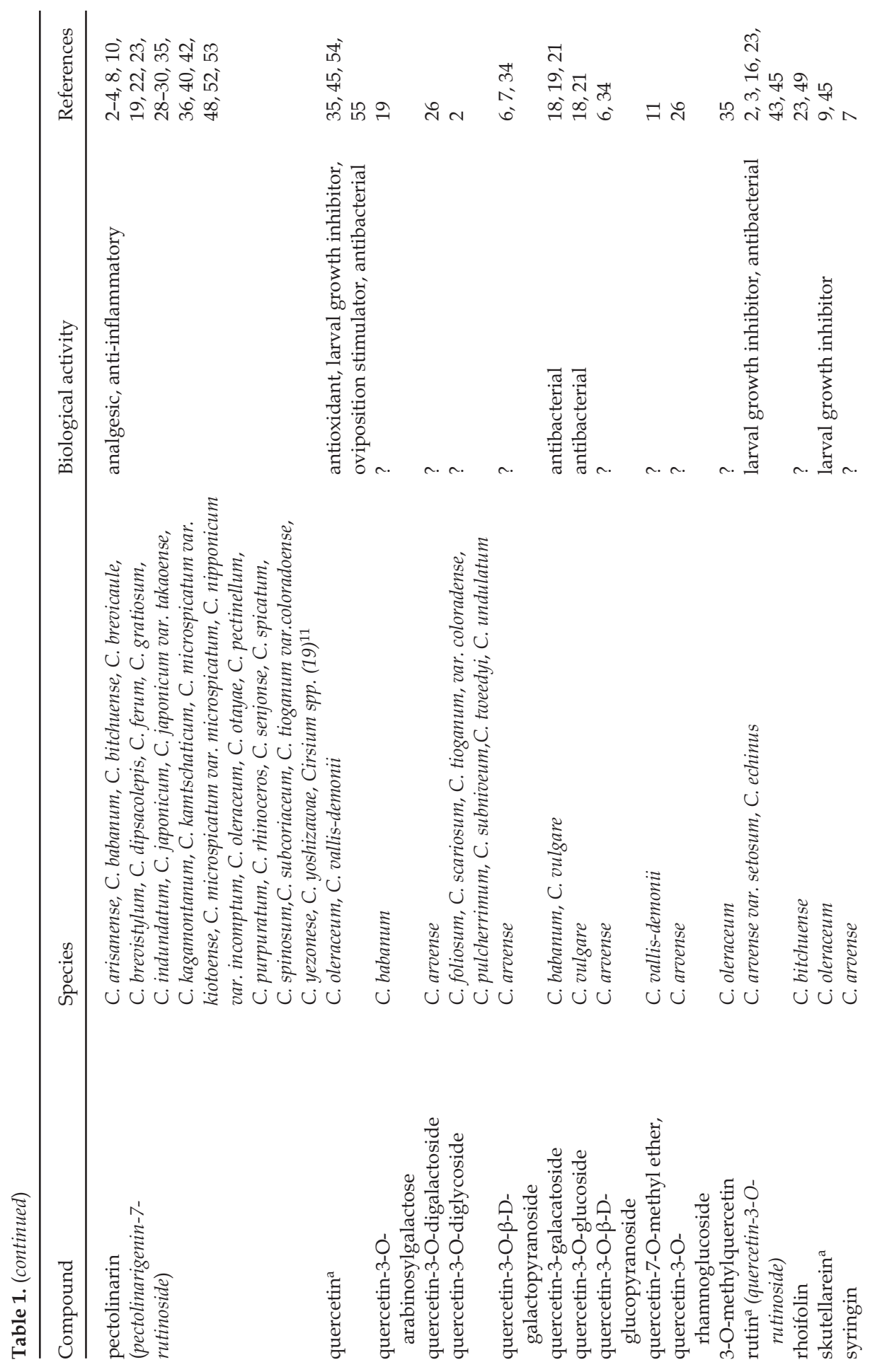




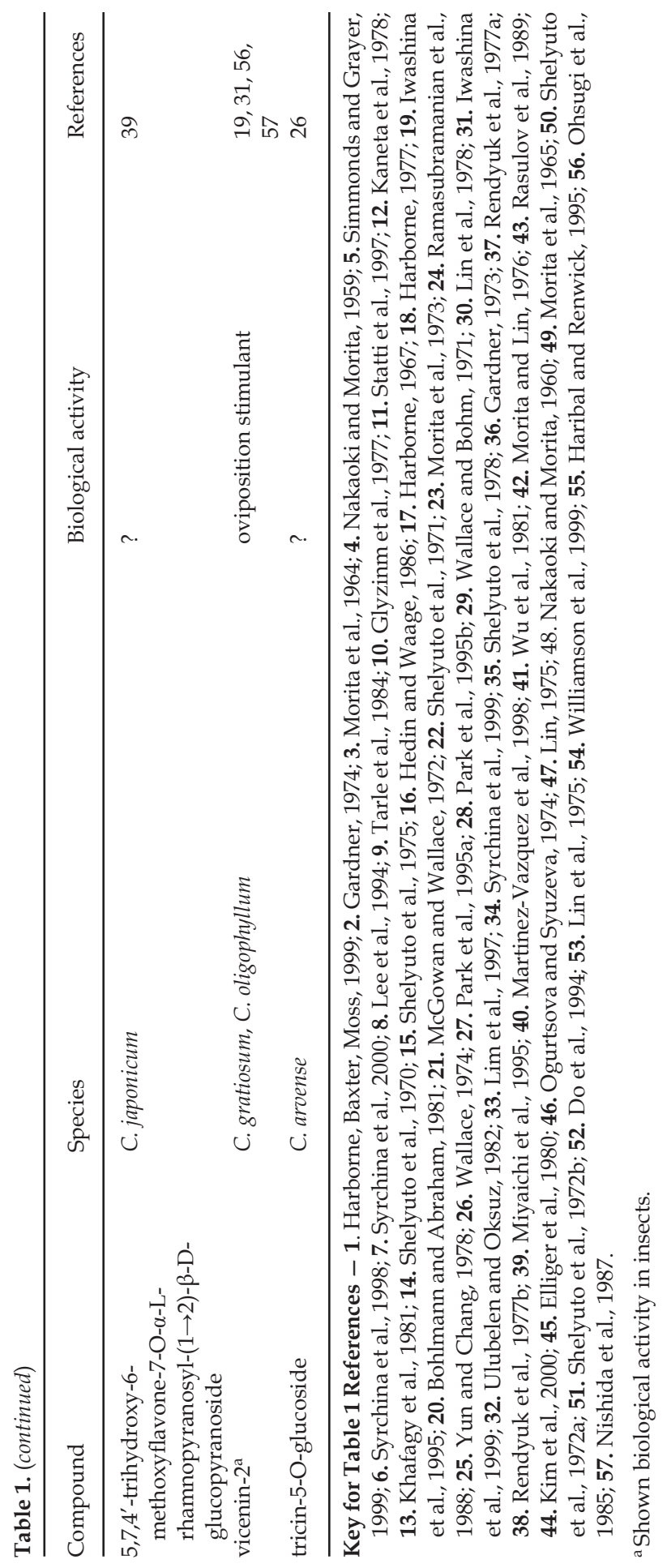


Table 2. Flavonoids reported in Carduus spp. by compound ${ }^{\text {a }}$

\begin{tabular}{|c|c|c|c|}
\hline Compound & Species & Biological activity & References \\
\hline apigenin $^{a}$ & $\begin{array}{l}\text { C. assoi, C. nutans, C. } \\
\text { pycnocephalus, C. } \\
\text { tenuiflorus }\end{array}$ & $\begin{array}{l}\text { anti-inflammatory, anti- } \\
\text { spasmodic, antibacterial, insect } \\
\text { attractant UV-pigment }\end{array}$ & ct ${ }^{1-10}$ \\
\hline apigenin-7-O-glucoside & $\begin{array}{l}\text { C. pycnocephalus, C. } \\
\text { nutans }\end{array}$ & $?$ & 7,10 \\
\hline apigenin-7-O-neohesperidoside & C. nutans & $?$ & 9 \\
\hline 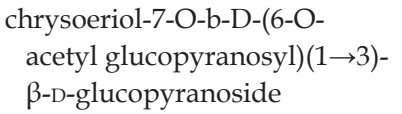 & C. pycnocephalus & antimicrobial & 11 \\
\hline diosmetin & C. pycnocephalus & antimicrobial & 11,12 \\
\hline $\begin{array}{l}\text { hispidulin (scutellarein } 6 \text { - } \\
\text { methyl ether) }\end{array}$ & C. assoi & cytotoxic & 13 \\
\hline $\begin{array}{l}\text { hispidulin-7-O- } \beta \text {-D- } \\
\text { glucopyranoside }\end{array}$ & C. assoi & $?$ & 5 \\
\hline isorhamnetin & C. nutans & $?$ & 8 \\
\hline kaempferol & $\begin{array}{l}\text { C. assoi, C. getulus, C. } \\
\text { nutans, C. tenuiflorus,C. } \\
\text { pyncocephalus }\end{array}$ & $?$ & $5,7,9$ \\
\hline $\begin{array}{l}\text { kaempferol-3,4'-dimethyl } \\
\text { ether-7-O-glucoside }\end{array}$ & C. pycnocephalus & $?$ & 7 \\
\hline $\begin{array}{l}\text { kaempferol-3-O-glucoside-7- } \\
\text { O-rhamnoside }\end{array}$ & C. nutans & $?$ & 9 \\
\hline $\begin{array}{l}\text { kaempferol-3-O- } \beta \text {-D- } \\
\text { glucopyranoside }\end{array}$ & C. assoi & $?$ & 5 \\
\hline $\begin{array}{l}\text { kaempferol-3-O- } \alpha \text {-L- } \\
\text { rhamnofuranoside }\end{array}$ & C. nutans & $?$ & 8 \\
\hline $\begin{array}{l}\text { kaempferol-3-O- } \alpha \text {-L- } \\
\text { rhamnoside }\end{array}$ & C. pycnocephalus & $?$ & 12 \\
\hline kaempferol-7-O-rhamnoside & C. nutans & ? & 9 \\
\hline $\begin{array}{l}\text { kaempferol-3-O- } \alpha \text {-L- } \\
\text { rhamnopyranose }\end{array}$ & C. assoi, C. tenuiflorus & $?$ & 5,6 \\
\hline $\begin{array}{l}\text { kaempferol-3-methyl ether-7- } \\
\text { O-glucoside }\end{array}$ & C. getelus & $?$ & 14 \\
\hline luteolin $^{a}$ & $\begin{array}{l}\text { C. acanthoides, } \\
\text { C. assoi, C. getulus, } \\
\text { C. nutans }\end{array}$ & $\begin{array}{l}\text { enzyme inhibitor ( } \alpha \text {-glucosidase } \\
\text { and } \alpha \text {-amylase) larval growth } \\
\text { inhibitor, antibacterial, insect } \\
\text { attractant as UV-pigment }\end{array}$ & se $2-5,10,15$ \\
\hline luteolin-7-O-galactoside & $\begin{array}{l}\text { C. acanthoides, } \\
\text { C. nutans }\end{array}$ & & 10 \\
\hline luteolin-7-O-digalactoside & C. acanthoides & & 10 \\
\hline luteolin-7-O-glucoside ${ }^{\mathrm{a}}$ & $\begin{array}{l}\text { C. acanthoides, } \\
\text { C.nutans }\end{array}$ & & 10 \\
\hline luteolin-7-O-diglucoside & C. nutans & & 10 \\
\hline luteolin-7-O-rutinoside & C. nutans & & 10 \\
\hline $\begin{array}{l}\text { luteolin-3-O- } \alpha \text {-L- } \\
\text { rhamnopyranoside }\end{array}$ & C. assoi & & 5 \\
\hline $\begin{array}{l}\text { luteolin-4-methyl ether-7-O- } \\
\text { glucoside }\end{array}$ & C. getelus & & 14 \\
\hline narnigenin & C. tenuiflorus & antibacterial & 2,6 \\
\hline
\end{tabular}


Table 2. (continued)

\begin{tabular}{|c|c|c|c|}
\hline Compound & Species & Biological activity & References \\
\hline quercetina & C. getulus & $\begin{array}{l}\text { antioxidant, larval growth } \\
\text { inhibitor, oviposition stimulator, } \\
\text { antibacterial }\end{array}$ & $\begin{array}{l}2,15,16, \\
17\end{array}$ \\
\hline quercetin 3,3-dimethyl ether & C. getulus & cytotoxic & 14 \\
\hline $\begin{array}{l}\text { rutin }{ }^{\mathrm{a}} \text { (quercetin-3-O- } \\
\text { rutinoside) }\end{array}$ & C. nutans & $\begin{array}{l}\text { larval growth inhibitor, } \\
\text { antibacterial }\end{array}$ & 2,8 \\
\hline tilianin & C. nutans & & 8 \\
\hline tricin & C. assoi & & 5 \\
\hline
\end{tabular}

Key for Table 2 References - 1, Simmonds and Grayer, 1999; 2, Hedin and Waage, 1986; 3, Harborne, 1967; 4, Harborne, 1977; 5, Fernandez et al., 1991; 6, Cardona et al., 1992b; 7, Amer et al., 1985; 8, Kaloshina and Mazulin, 1988; 9, Abdallah et al., 1989; 10, Bain and Desrochers, 1988; 11, El-Lakany et al., 1997; 12, El-Lakany et al., 1995; 13, Ulubelen and Oksuz, 1982; 14, Abdel-Salam et al., 1982; 15, Elliger et al., 1980; 16, Williamson et al., 1999; 17, Haribal and Renwick, 1996.

a Shown biological activity in insects.

Renwick, 1996). Vicenin-2, rutin, narirutin and hesperidin (together, but not individually) were strong oviposition stimulants for Papilio xuthus (Ohsugi et al., 1985; Nishida et al., 1990). Both vicenin-2 and rutin have been found in some Cirsium and Carduus species (below).

\subsubsection{Occurrence and activity in Cirsium and Carduus}

We found 78 flavonoids reported from Cirsium spp. and 31 from Carduus spp. (Tables 1 \& 2). Three of the six flavonoid groups were reported: flavonols, flavones, and one isoflavone. The compounds most often reported for both Carduus and Cirsium (Tables 1 \& 2) were: apigenin, cirsimaritin, kaempferol, linarin, luteolin, pectolinarin, and quercetin (with various glycosides attached). Ten flavonoid groups were shared between Cirsium and Carduus. Cirsium spp. had 11 groups of flavonoids reported that were not found in Carduus spp., while two flavonoids were reported only from Carduus spp.

Linarin and pectolinarin, known to have anti-inflammatory properties (Table 1), are common in Cirsium spp. but have not been studied for their biological activity towards insects. Other less common compounds with known biological activity included: diosmetin, vicenin-2, skutellarein, and rutin (Tables 1 $\& 2$ ). Antimicrobial activity was identified in diosmetin (Haribal and Renwick, 1996). Vicenin-2 was isolated from Cirsium oligophyllum (Iwashina et al., 1995, 1999). Rutin was found in Cirsium echinus, C. arvense var. setosum, and C. undulatum, (Morita et al., 1964, 1973; Gardner, 1973; Elliger et al., 1980; Rasulov et al., 1989) and Carduus nutans (Hedin and Waage, 1986; Kaloshina and Mazulin, 1988). The literature suggests both a high frequency of occurrence in flavonoids, and both overlap and variation in these compounds among Cirsium and Carduus species. 


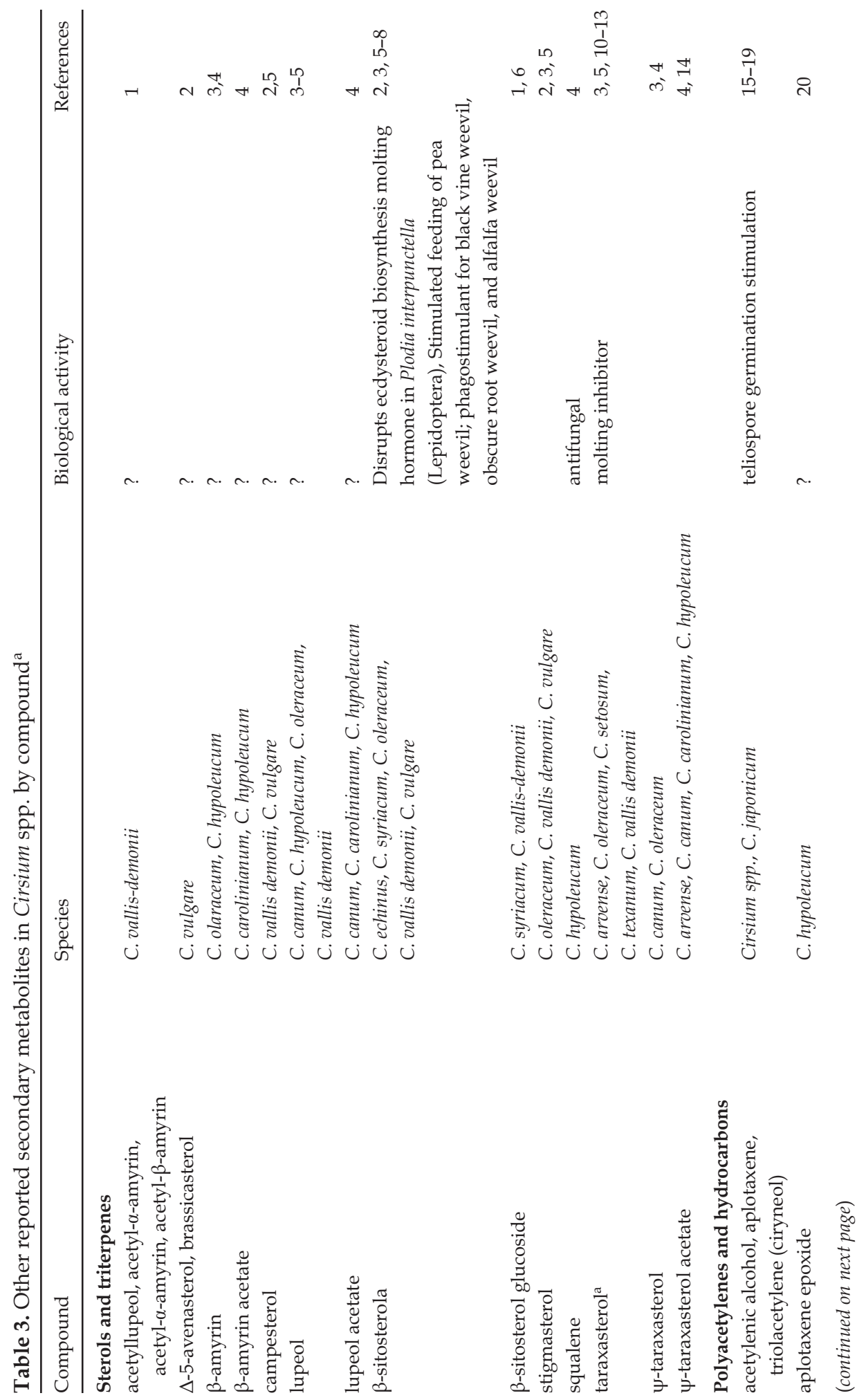




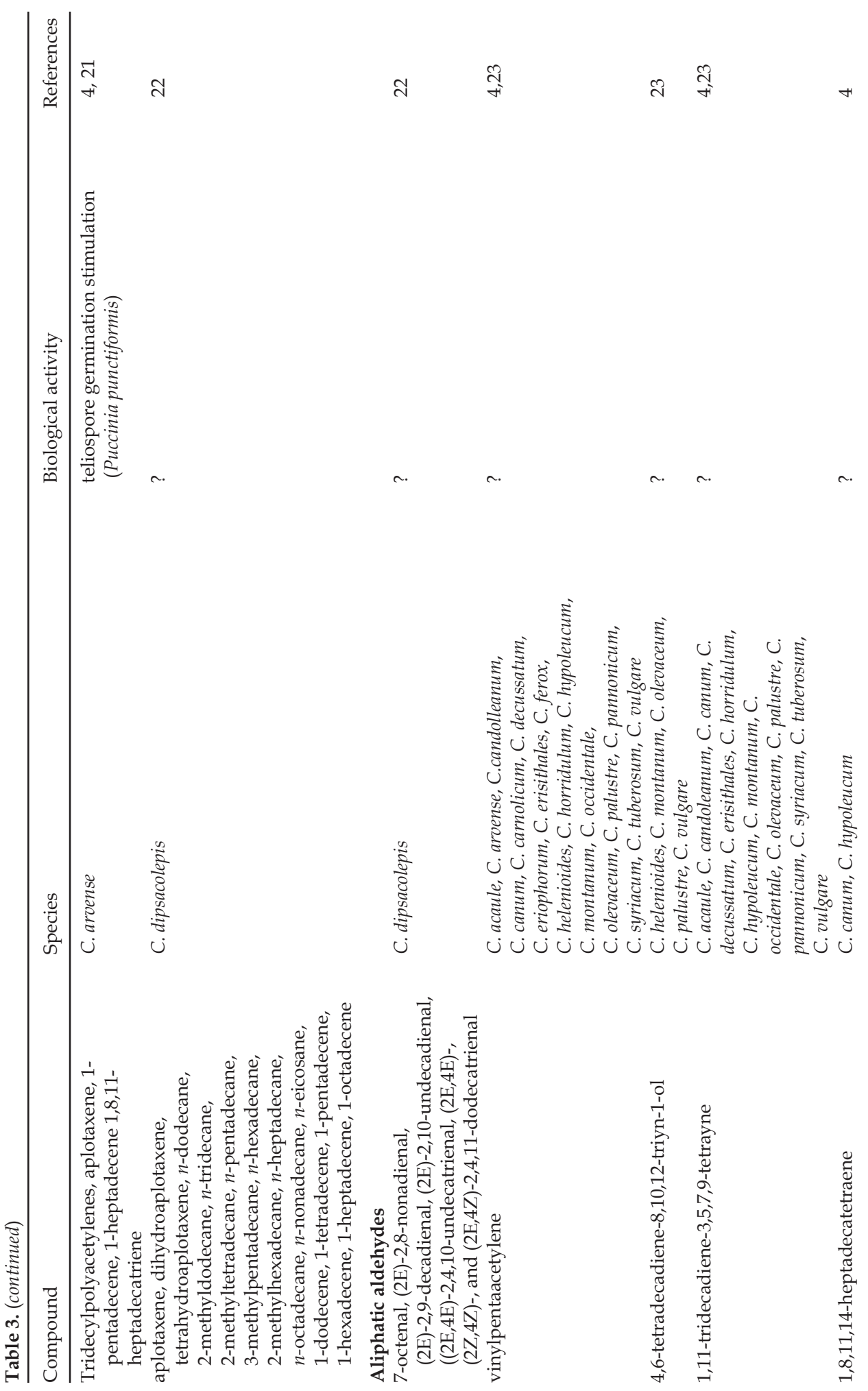




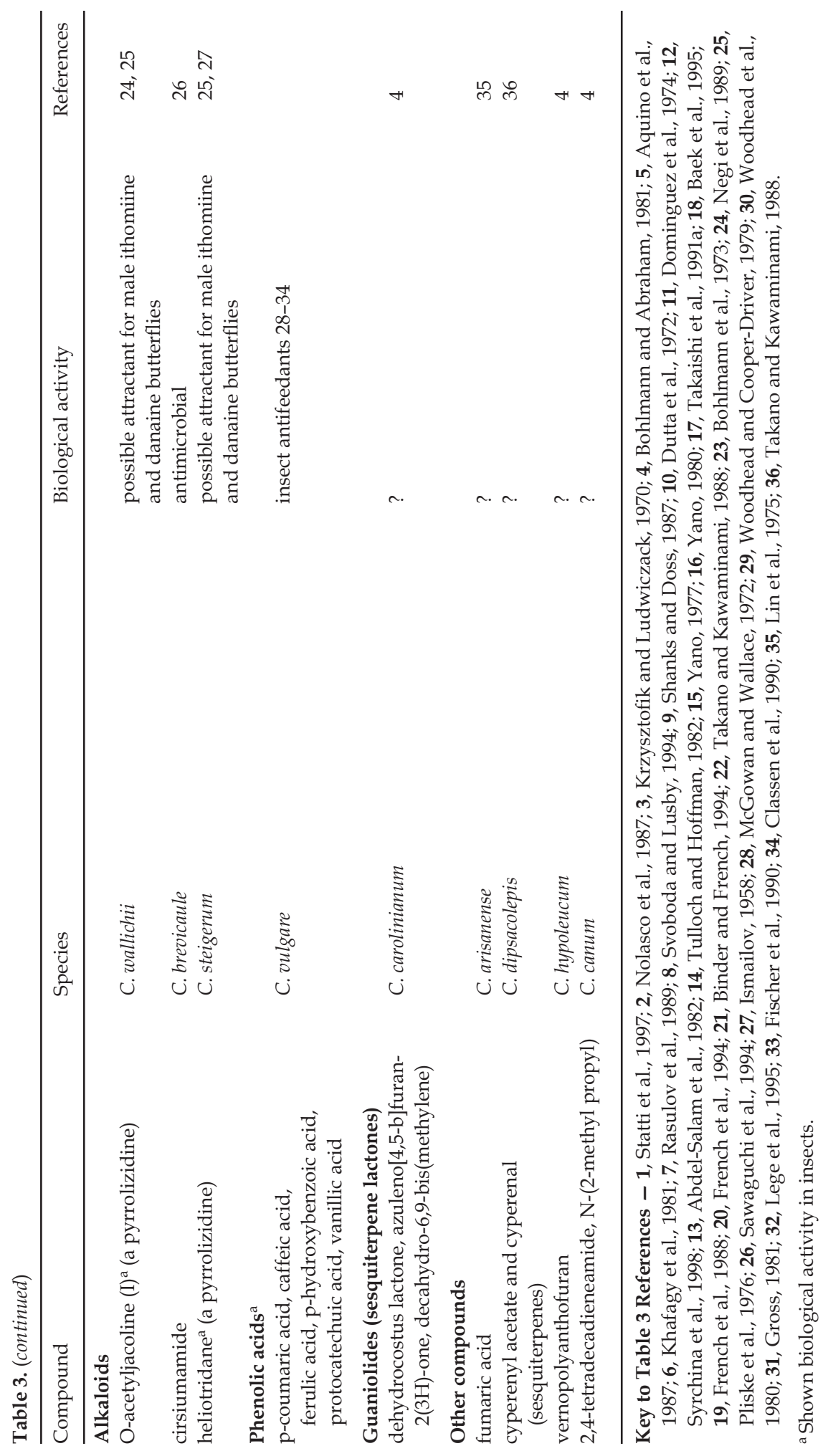


Table 4. Other reported secondary metabolites in Carduus spp. by compound ${ }^{\mathrm{a}}$

\begin{tabular}{|c|c|c|c|}
\hline Compound & Species & Biological activity References & \\
\hline \multicolumn{4}{|l|}{ Sterols and triterpenes } \\
\hline lupeol & C. pycnocephalus & $?$ & 3 \\
\hline$\beta$-sitosterol ${ }^{\mathrm{a}}$ & $\begin{array}{l}\text { C. acanthoides, C. getulus, } \\
\text { C. pycnocephalus, C. nutans }\end{array}$ & $\begin{array}{l}\text { Disrupts ecdysteroid } \\
\text { biosynthesis molting hormone } \\
\text { in Plodia interpunctella } \\
\text { Stimulated feeding of pea } \\
\text { weevil; phagostimulant for } \\
\text { black vine weevil, obscure root } \\
\text { weevil, and alfalfa weevil }\end{array}$ & $1-7$ \\
\hline$\beta$-sitosterol glucoside & C. pycnocephalus & $?$ & 3 \\
\hline sitosterol-3-O-xyloside & C. nutans & $?$ & 7 \\
\hline $\begin{array}{l}\text { taraxasterol acetate }^{\mathrm{a}} \\
\text { taraxasterol }^{\mathrm{a}}\end{array}$ & C. getulus, C. nutans & molting inhibitor & $1,2,7$ \\
\hline $\begin{array}{l}\Delta \text {-5-avenasterol, } \\
\text { brassicasterol, campesterol, } \\
\text { stigmasterol }\end{array}$ & C. acanthoides & $?$ & 4 \\
\hline \multicolumn{4}{|l|}{$\begin{array}{l}\text { Polyacetylenes and } \\
\text { hydrocarbons }\end{array}$} \\
\hline vinylpentaacetylene & $\begin{array}{l}\text { C. argyroa, C. collinus, } \\
\text { C. glaucus, C. leucophyllus, } \\
\text { C. nigrescens, C. nutans, } \\
\text { C. personata, C. pycnocephalus }\end{array}$ & $?$ & 8 \\
\hline $\begin{array}{l}\text { 4,6-tetradecadiene-8,10,12- } \\
\text { triyn-1-ol }\end{array}$ & C. leucophyllus & $?$ & 8 \\
\hline $\begin{array}{l}\text { 1,11-tridecadiene-3,5,7,9- } \\
\text { tetrayne }\end{array}$ & C. nigrescens, C. personata & $?$ & 8 \\
\hline $\begin{array}{r}\text { 2,6,8,14-tetradecatetraene-4- } \\
\text { yne-10,11,12,13-methylene }\end{array}$ & C. argyroa, C. collinus & $?$ & 8 \\
\hline $\begin{array}{l}\text { Alkaloids } \\
\text { acanthoidine, acanthoine, } \\
\text { ruscopine }\end{array}$ & C. acanthoides & $\begin{array}{l}\text { (acanthoidine only) hypotensive } \\
\text { (dog and human) }\end{array}$ & $9-11$ \\
\hline \multicolumn{4}{|l|}{ Coumarins } \\
\hline $\begin{array}{l}\text { 6-prenyloxy-7- } \\
\text { methoxycoumarin, } \\
\text { isoescopoletin, isofraxidin }\end{array}$ & C. tenuiflorus & $?$ & 12 \\
\hline \multicolumn{4}{|l|}{ Lignans } \\
\hline $\begin{array}{l}\text { 1-hydroxypinoresinol, } \\
\text { pinoresinol, a syringaresinol }\end{array}$ & C. assoi, C. tenuiflorus & $\begin{array}{l}\text { (pinoresinol only) Toxicity to } \\
\text { 4th instar milkweed bug larvae } \\
\text { and blood sucking bug. } \\
\text { Pinoresinol has antimolting } \\
\text { activity }\end{array}$ & 13,14 \\
\hline $\begin{array}{l}\text { 2-hydroxyolivil, } \\
\text { laricinresinol, prinsepiol }\end{array}$ & C. assoi & $?$ & 15 \\
\hline
\end{tabular}

Key to Table 4 References - 1, Abdel-Salam et al., 1982; 2, Abdel-Salam et al., 1983; 3, El-Lakany et al., 1995; 4, Nolasco et al., 1987; 5, Svoboda and Lusby, 1994; 6, Shanks and Doss, 1987; 7, Abdallah et al., 1989; 8, Harborne et al., 1999; 9, Frydman and Deulofeu, 1962; 10, Boidadzhiev, 1964; 11, Cabral et al., 1999; 12, Cabral et al., 2000; 13, Fernandez et al., 1991; 14, Bohlmann et al., 1973; 15, Cardona et al., 1992b.

a Shown biological activity in insects. 


\subsection{Sterols and triterpenes}

\subsubsection{Chemistry}

The second most common secondary metabolites in Cirsium and Carduus species were sterols and triterpenes (Tables 3 \& 4). Little is known, however, about their activity with respect to insect specialists on these genera. Sterols and triterpenoids are classes of terpenoids (isoprenoids). Terpenoids are derived from isopentenyl and dimethylallyl pyrophosphates (Bramley, 1997), and the sterols are derived from triterpenoids $\left(C_{30}\right)$, the largest class (Harborne, 1999). Triterpenoinds are generally classified as membrane constituents, occurring mostly in leaf glandular trichomes, bud exudates, and bark resins (Harborne, 1999). Glandular trichomes or resin ducts often are found on the involucural bracts of Cirsium spp. (Great Plains Flora Association, 1986; Bremer, 1994; personal observation).

\subsubsection{Biological activity}

Most research on the effects of plant sterols and triterpenes on insects are related to their effect on hormonal activity, often with the aim of employing them as insecticides (Prestwich, 1986). Sterols have an antagonistic effect on the ability of larvae to molt (Alder, 1995; Luu and Werner, 1996; Dugassa-Gobena et al., 1998), since insect metabolism is vulnerable to dietary sterols (Feldlaufer and Svoboda, 1988; Darvas, 1991; Svoboda, 1992). On the other hand, some insects incorporate ingested sterols into their metabolism, relying upon them for their molting hormones (Svoboda et al., 1991, 1994). For example, a lepidopteran (Plodia interpunctella) used synthetic $\beta$-sitosterol, a compound found in Cirsium and Carduus spp., as a dietary source to produce cholesterol (Svoboda and Lusby, 1994), essential to the production of ecdysteroid molting hormones (Svoboda et al., 1991). Additionally, $\beta$-sitosterol stimulated feeding by several weevils, such as the pea leaf weevil (Sitona lineatus), black vine weevil (Oiorhynchus sulcatus), obscure root weevil (Sciopithes obscurus), and alfalfa weevil (Hypera postica) (Shanks and Doss, 1987).

\subsubsection{Occurrence and activity in Cirsium and Carduus}

The sterol, $\beta$-sitosterol, which can affect insect molting (above), was reported from five of the 92 Cirsium spp. studied (C. echinus, C. oleraceum, C. syriacum, C. vallis demonii, C. vulgare), as well as four of the 12 Carduus spp. (C. acanthoides, $C$. getulus, C. pycnocephalus, C. nutans) (Tables 3 \& 4). The triterpenes, taraxasterol acetate, taraxasterol and erythrodiol-3-acetate, extracted from Carduus getulus inhibited molting of the cotton leafworm (Spodoptera littoralis) (Abdel-Salam et al., 1982). Taraxasterol acetate and taraxasterol also were found in eight Cirsium spp. (C. arvense, C. canum, C. carolinianum, C. hypoleucum, C oleraceum, C. setosum, C. texanum, C. vallis demonii) (Table 3), as well as two Carduus spp. (Carduus getulus, C. nutans) (Table 4). Tulloch and Hoffman (1982) found $\psi$-taraxasterol acetate (and other uncommon compounds) in the epicuticlar wax of Cirsium arvense. Although other sterols and triterpenes are reported from Cirsium and Carduus spp. (Tables $3 \& 4$ ), their biological activity has not been evaluated. 


\subsection{Polyacetylenes, acetylenes and other hydrocarbons}

\subsubsection{Chemistry}

These groups of compounds are grouped, based on the similarity of their structure, long hydrocarbon chains. Polyacetylenes and acetylenes are characteristic of the Asteraceae (Bohlmann et al., 1973; Baek et al., 1995; Harborne et al., 1999). Polyacetylenes are fatty acid derivatives that are generally stored in secretory plant cells, called laticifers (Mauseth, 1988; Ellis, 1997), that secrete latex. Viscous exudates, such as latex, usually contain secondary metabolites (Mauseth, 1988). Most true thistles have clear latex that exudes upon damage from most organs of the plant. Aphid clusters have been observed on some Cirsium spp. around exuded droplets likely to be latex (Bremer, 1994; personal observation). The chemical profile of these exudates of thistles does not appear to have been characterized. However, polyacetylenes are reported to be common and characteristic in thistle roots (below).

\subsubsection{Biological activity}

Polyacetylenes from the Asteraceae have been reported to have major antifeedant properties, including against root-feeding insects of thistles (e.g. Yano, 1977; Bohlmann and Abraham, 1981; Aquino et al., 1987; Negi et al., 1989; Takaishi et al., 1990, 1991a, 1991b; Binder et al., 1992; Binder and French, 1994; Shen and Mu, 1990; Stevens et al., 1990; Christensen, 1992; Sawaguchi et al., 1994). Polyacetylenes from leaves of rabbitbrush, Chrysothamnus nauseosus, had antifeedant properties against the Colorado potato beetle, Leptinotarsa decemlineata (Rose et al., 1980). All four polyacetylenes found inhibited feeding by third instar larvae of $L$. decemlineata. Phenylheptatriyne (PHT) from Asteraceae also had antifeedant effects on the moth, Euxoa mossoria (McLachlan et al., 1982). In addition, both synthetic polyacetylenes and those extracted from various Asteraceae species had insecticidal properties on mosquito larvae (Arnason et al., 1981; Wat et al., 1981; Towers et al., 1984; Wang et al., 1990; Guillet et al., 1997; Wan et al., 2000). Alternately, however, some polyacetylenes were reported to stimulate feeding by insect specialists on Asteraceae, such as the leaf beetle Chrysolina aurichalcea (Matsuda et al., 1982).

\subsubsection{Occurrence and activity in Cirsium and Carduus}

Almost all of the polyacetylenes and hydrocarbons reported from Cirsium and Carduus (Tables $3 \& 4$ ) were from roots rather than above-ground organs (Table 3). The one exception was a heptadecatetraene, which was isolated from the aerial parts of Cirsium hypoleucum and C. canum (Bohlmann and Abraham, 1981). In the extensive study of the roots of Cirsium dipsacolepis, eight aliphatic aldehydes and 24 hydrocarbons were isolated, but their biological activity is unknown (Takano and Kawaminami, 1988; Table 3). Takano and Kawaminami (1988) found that almost $80 \%$ of the volatile oils extracted from the roots of Cirsium dipsacolepis were made up of aplotaxene and four derivates of aplotaxene. In an extensive review of naturally occurring acetylenes, Bohlmann et al., (1973) found four main compounds in many Cirsium and Carduus spp. (Tables $3 \& 4$ ). None of these four have 
been investigated for their biological activity. Most of the literature on the biological activity of polyacetylenes in thistles concerns their effect on Canada thistle rust (Puccinia punctiformis), a root-borne thistle fungus. Polyacetylenes and hydrocarbons from Cirsium spp. roots influenced fungal colonization. These compounds included: acetylenic alcohol, aplotaxene, triolacetylene, aplotaxene epoxide, tridecylpolyacetylene, 1-pentadecene, 1-heptadecene, and 1,8,11-heptadecatriene (Table 3). Polyacetylenes from Canada thistle (Cirsium arvense) stimulated germination of P. punctiformis teliospores (Whitehead et al., 1982; French, 1990; Shen and Mu, 1990; Christensen, 1992; Eskelesen and Crabtree, 1995). Furthermore, some evidence suggests polyacetylenes can influence interactions among plant hosts. For example, Eskelesen and Crabtree (1995) found that polyacetylenes in Cirsium arvense acted as allelopathic compounds against neighboring plants. Research is needed to determine if polyacetylenes occur in foliage or flower heads of Cirsium or Carduus spp., where an effect on host choice by nonrootfeeding thistle insects might occur.

\subsection{Alkaloids}

\subsubsection{Chemistry}

Alkaloids (>12 000 structures) have been detected in about $15 \%$ of all plants, bacteria, fungi, and animals (Wink, 1997). Alkaloids are a heterogeneous group of nitrogen-containing compounds, specifically those that are not otherwise recognizable as peptides, nonprotein-amino acids, amines, cyanogenic glycosides, glucosinolates, cofactors, phytohormones or primary metabolites, such as purines or pyrimidines (Wink, 1997). Alkaloids are derived from amino acids joined with moieties derived from other pathways, such as terpenoids. Most alkaloids are synthesized in the cytoplasm and stored in plant cell vacuoles, although some are sequestered into latex (Wink, 1997). Alkaloids sometimes are more concentrated in epidermal tissues than in the mesophyll (Wink, 1986), and they usually are associated with organs essential for plant survival: flowers, seeds, and roots (Wink, 1997).

\subsubsection{Biological activity}

Alkaloids function as chemical defenses against herbivores and microbes and as allelopathic compounds against plant competitors (Harborne, 1993). Typically alkaloids are deterrents to feeding by generalist insects, but attractants for more specialized insects. For example, quinolizidine alkaloids in Genista mospessulana are thought to maintain exclusive host use by Uresiphita reversalis (Lepidoptera: Pyralidae) (Montlor et al., 1990). Also, pyrrolizidine alkaloids of Heliotropium indicum are powerful attractants for male Ithomiine and Danaine butterflies to their host plant (Pliske et al., 1976).

\subsubsection{Occurrence and activity in Cirsium and Carduus}

Six alkaloids are reported from Cirsium (Table 3) or Carduus spp. (Table 4). Two are pyrrolizidine alkaloids (Figure 1): O-acetyljacoline (I) from Cirsium wallichii (Negi et al., 1989) and heliotridane from Cirsium steigerum (Ismailov, 1958). Both 
of these were among the attractant compounds for male Ithomiine and Danaine butterflies (Pliske et al., 1976). One other alkaloid (1-N-(p-coumaroyl) pipecolic acid), reported in Cirsium brevicaule, showed antibacterial activity against the bacteria: Staphylococcus typhimurium, Pseudomonas aeruginosa, and P. vulgaris (Sawaguchi et al., 1994). Other alkaloids reported from Carduus acanthoides (acanthoine, acanthoidine, ruscopine) were found primarily in the roots; these compounds showed hypotensive effects on dogs and humans (Frydman and Deulofeu, 1962; Harborne et al., 1999). We found no direct tests of the effect of any of the alkaloids found in thistles on insect host choice.

\subsection{Sesquiterpene lactones}

\subsubsection{Chemistry}

Over 3000 structures are known for this subset of terpenoids (Harborne, 1999). Sesquiterpenoids make up hundreds of groups with similar backbones, and the sesquiterpene lactones contain four major groups of these backbones. These compounds have been studied as chemosystematic markers, but not for true thistles. These groups of terpenoids, derived from the isopentyl and dimethylallyl diphosphates, are characterized by a 15-carbon skeleton containing a lactone ring (Gershenzon and Croteau, 1991; Bramley, 1997). Sesquiterpene lactones are often associated with specialized secretory structures, such as glands or glandular trichomes (Loomis and Croteau, 1973; Kelsey and Shafizadeh, 1980; Rossiter et al., 1986; Bramley, 1997), similar to those observed on some thistle flower heads.

\subsubsection{Biological activity}

Reported biological activity of the sesquiterpene lactones from the Asteraceae is significant (Rodriguez et al., 1976; Picman, 1986; Rosenthal and Berenbaum, 1991). These compounds influence many organisms, including insects (e.g. Mabry and Gill, 1977; Kelsey and Shafizadeh, 1980; Harmatha and Nawrot, 1984; Rees and Harborne, 1985; Picman, 1986; Rossiter et al., 1986; Arnason et al., 1987; Harborne, 1990; Callaway et al., 1999). Insect responses are widely variable and complicated. Cnicin (a guaianolide) is a bitter antifeedant for generalist insects (Landau et al., 1994; Harborne et al., 1999), but an oviposition and development stimulant for specialist insects on Centaurea spp. (Landau et al., 1994). Glaucolide A deterred feeding by larvae of six lepidopterans: southern armyworm, fall armyworm, yellow wooly bear, cabbage looper, and yellow striped armyworm (Burnett and Jones, 1974). Nawrot et al. (1983) found a deterrent effect of eight sesquiterpene lactones from Laserpitium siler, L. archangelica, and Laser trilobum against three generalist beetles: Sitophilus granaries, Tribolium confusum, and Trogoderma granarium. Sesquiterpene lactones and lignan lactones from three other Asteraceae (Eupatorium cannabinum, Homogyne alpine, Petasites albus) reduced feeding by these insects (Harmatha and Nawrot, 1984). Sesquiterpene lactones (lactucin, lactupicrin and 8-deoxylactucin) in the milky latex of chicory, Cichorium intybus, displayed a marked deterrence of feeding by the polyphagous acridid grasshopper, Schistocerca gregaria (Rees and Harborne, 1985). 


\subsubsection{Occurrence and activity in Cirsium and Carduus}

The sesquiterpene lactones from the thistle tribe (Cardueae) have not been analyzed intensively for true thistles (Subtribe Carduineae). However, they have been for the related knapweeds (Subtribe Centaurineae), likely because of their role in folk medicines and their potential insecticidal properties (Rodriguez et al., 1976; Picman et al., 1978; Rees and Harborne, 1985; Picman, 1986). The sesquiterpene lactones found in knapweeds belong to three subgroups: elemanolides, germacranolides, and guainolides. A small fraction of the common compounds reported in Centaurea spp. include: acroptilin, cnicin, and cynaropicrin (e.g. Oksuz and Putun, 1983; Locken and Kelsey, 1987; Benayache et al., 1992; Youssef and Frahm, 1994; Harborne et al., 1999). Cnicin, extracted from Centaurea maculosa and $C$. vallesiaca, when sprayed on artificial diets stimulated oviposition by the specialist lepidopteran insects: Stenoides straminea, Agapeta zoegana (Cochylidae), Pterolonche inspersa (Pterolonchidae) (Locken and Kelsey, 1987). However, larvae of a generalist lepidopteran (Spodoptera littoralis) did not survive on the cnicintreated diets. In Nebraska, thistles are hosts to species of moth larvae in the genus Homoeosoma spp. (e.g. H. impressale on Cirsium canescens and C. undulatum: Louda, 1998). Although these species have not been tested, the related Homoeosoma electellum (sunflower moth) from Helianthus annuus has been. The exudates from glandular trichomes in sunflower, $H$. annuus, contained more than five sesquiterpene lactones; these decreased feeding by H. electellum significantly, although the effect decreased as larva developed (Rossiter et al., 1986). In fact, H. electellum experienced higher mortality, retarded growth, and an extended development period in the presence of sesquiterpene lactones from the glandular trichomes (Rossiter et al., 1986).

Surprisingly, given the prevalence and activity of these compounds in other composites, including close relatives, we found only one report of sesquiterpene lactones in Cirsium spp.

Two guaianolides, dehydrocostus lactone and azuleno[4,5-b]furan-2-(3H)one, decahydro-6,9-bis(methylene), were isolated from the roots of Cirsium carolinianum (Bohlmann and Abraham, 1981). The only other reports we found for a Carduus species (Andronescu et al., 1984; Kataria, 1995; Bicchi and Rubiolo, 1996) was for a plant species (C. benedictus) that has since been reclassified into the genus Cnicus, a genus more closely related to Centaurea than to Carduus (Dittrich, 1977; Bremer, 1994).

\subsection{Phenolic acids}

\subsubsection{Chemistry}

The term "phenolic acids" describes a variety of organic compounds bearing one or more phenolic hydroxyl group and a carboxyl function (Gross, 1981). The total number of phenolics, including flavonoids, is over 8000 (Harborne, 1999). Like flavonoids and other phenolic compounds, they originate in the shikimate pathway (Harborne, 1999). Most phenolics are found in conjunction with sugars in watersoluble forms in the vacuole. Some commonly occurring phenolic acids, like hydroxybenzoic acid, can be found in almost any part of a plant (Harborne, 1999). 


\subsubsection{Biological activity}

Phenolic acids can affect insect behavior (Gross, 1981). For example, reduced feeding by various grasshoppers and by a planthopper, Peregrinus maidis, was correlated with high concentrations (dry weight) of total phenolic acids (Woodhead et al., 1980). Also, ferulic acid was shown to be involved in maize resistance to the weevil Sitophilus zeamais (Classen et al., 1990). More than half of the common phenolic acids that were tested reduced feeding of the Mexican bean beetle (Coccinellidae) when sprayed on to leaves of its preferred host, the common bean Phaseolus vulgaris (Fischer et al., 1990). Additionally, high levels of phenolic acid content in the older leaves (0.3-1.0\%) of Sorghum bicolor significantly reduced feeding by Locusta migratoria (Woodhead and Cooper-Driver, 1979). Lege et al. (1995) suggested that resistance in cotton (Gossypium hirsutum) to spider mite (Tetranychus urticae) might be attributed to high levels of the condensed tannins and phenolic acids.

\subsubsection{Occurrence and activity in Cirsium and Carduus}

Phenolic acids found in cotton also have been found in Cirsium spp. (Table 3). Cirsium vulgare, for example, contains many of the compounds tested from cotton: $p$-coumaric, caffeic, ferulic, $p$-hydroxybenzoic, protocatechuic and vanillic acids (McGowan and Wallace, 1972). This group could influence host choice behavior; higher oviposition rates by $R$. conicus, for example, are correlated with feeding on leaf material prior to flower presentation (Louda, unpublished data). However, the importance of this group of compounds in host preference and acceptance by thistle insects is unknown.

\subsection{Lignans}

\subsubsection{Chemistry}

Lignans, a distinct class of phenolics, are phenylpropanoid dimers (Figure 1) that are derived from coniferyl alcohol (Strack, 1997; Walton and Brown, 1999). Lignans are common constituents of wood and bark, i.e. secondary growth cells (Harborne, 1999).

\subsubsection{Biological activity}

Lignans have the ability to bind to estrogen receptors in humans (Williamson et al., 1999), so they are considered phytoestrogens. Lignans and related compounds, reported active in preventing breast and prostate cancer and delaying menopause, are found in many plants common in human diets (Mazur and Adlercreutz, 1998; Gordaliza et al., 2000; Thompson, 2000). We found reports of antimicrobial, antifungal, and antifeedant effects of lignans (Strack, 1997). A lignan, [+]-epimagnolin A, extracted from the buds of Magnolia fargesii inhibited growth of Drosophila melanogaster larvae (Miyazawa et al., 1994). In another study, the lignan podophyllotoxin given orally or applied topically to a beetle, Rhodnius proxlixus, inhibited molting (Cabral et al., 2000). The lignanamide demethylgrossamide, found in a methanolic extraction of Xylopia aethiopica seeds, exhibited potent deterrence of feeding by the subterranean termite, Reticulitermes speratus, at $5000 \mathrm{ppm}$ (Lajide et 
al., 1995). Lignans (gomisin B, gomisin N) in the fruits of Schisandra chinensis were insecticidal for Drosophila melanogaster (Miyazawa et al., 1998).

\subsubsection{Occurrence and activity of lignans in Cirsium and Carduus}

No lignans were reported in Cirsium spp. (Table 3), but five were reported in Carduus spp. (Table 4). Pinoresinol, found in Carduus assoi and C. tenuiflorus (Fernandez et al., 1991; Cardona et al., 1992a; Cabral et al., 1999), is the only lignan known from thistles for which effects on insects have been reported. Pinoresinol, also common in spruce and pine trees (Strack, 1997), exhibits anti-molting activity (58\% molting inhibition) to the 4 th instar milkweed bug larvae, Oncopeltus fasciatus, and the blood-sucking bug, Rhodnius prolixus (Cabral et al., 1999, 2000). Effects reported were dose-dependent: an effect was seen with an oral dose of 100 $\mu \mathrm{g} / \mathrm{ml}$. Also, pinoresinol has similar structure to [+]-epimagnolin A (Figure 1), which was reported to inhibit fly growth (above). The biological activity of the other lignans reported in Carduus assoi and C. tenuiflorus (Table 4) is unknown.

\subsection{Other compounds}

Two sesquiterpenes, cyperenyl acetate and cyperenal, were isolated from the roots of Cirsium dipsacolepis (Takano and Kawaminami, 1988). An unsaturated dibasic acid, fumaric acid, was isolated from leaves of Cirsium arisanense (Lin et al., 1975). These are unique compounds and their biological activity has not been studied.

\section{Discussion}

If, as hypothesized, host chemistry dominates the factors influencing field host preference (Becerra, 1997; Becerra and Venable, 1999), then studies of chemical ecology as part of the screening of biological control candidates could be an important new tool in risk assessment. Among the thistle species for which chemical data exist (Tables 1-4), we found both important similarities and striking differences in the known chemical profiles between Carduus, a predominantly Eurasian genus, and Cirsium, the Palearctic genus that contains North American thistles, and among Cirsium spp. (Tables 5-7). These findings are consistent with the hypothesis that comparative analyses of secondary metabolites, with specific information on biological activity, potentially could provide added predictive power for potential host choice and use by exotic insects in biological control of weeds. The evidence compiled here provides an initial framework for such screening in future thistle control projects, such as in contemporary efforts to find host-specific biological control agents for the Eurasian Cirsium arvense (Canada thistle) in North America.

\subsection{Comprehensiveness of the data}

We were surprised to find that only a small proportion of Cirsium spp. and Carduus spp. has been studied for their chemistry and biological activity. In the genus 
Table 5. Flavonoid groups in Cirsium and Carduus spp $\mathrm{p}^{\mathrm{a}, \mathrm{b}}$

\begin{tabular}{|c|c|c|c|c|c|c|}
\hline & Cirsium & $\begin{array}{r}\text { No. of } \\
\text { derivatives }\end{array}$ & No. of spp. & Carduus & $\begin{array}{r}\text { No. of } \\
\text { derivatives }\end{array}$ & $\begin{array}{l}\text { No. of } \\
\text { spp. }\end{array}$ \\
\hline \multicolumn{7}{|l|}{ Cirsium only } \\
\hline acacetin & + & 3 & 5 & - & & \\
\hline cirsiliol & + & 3 & 1 & - & & \\
\hline cirsimaritin & + & 3 & 10 & - & & \\
\hline genkwanin & + & 1 & 1 & - & & \\
\hline linarin & + & $\mathrm{n} / \mathrm{a}$ & 26 & - & & \\
\hline nepetin & + & 2 & 1 & - & & \\
\hline pectolinarin & + & 4 & 29 & - & & \\
\hline rhoifolin & + & $\mathrm{n} / \mathrm{a}$ & 1 & - & & \\
\hline skutellarin $^{\mathrm{c}}$ & + & $\mathrm{n} / \mathrm{a}$ & 1 & - & & \\
\hline syringin & + & $\mathrm{n} / \mathrm{a}$ & 1 & - & & \\
\hline vicenin- $2^{c}$ & + & $\mathrm{n} / \mathrm{a}$ & 2 & - & & \\
\hline \multicolumn{7}{|c|}{ Cirsium and Carduus } \\
\hline apigenin $^{c}$ & + & 11 & 22 & + & 3 & 4 \\
\hline chrysoeriol & + & 4 & 6 & + & 1 & 1 \\
\hline diosmetin & + & 1 & 3 & + & 1 & 1 \\
\hline hispidulin & + & 5 & 5 & + & 2 & 1 \\
\hline kaempferol & + & 9 & 5 & + & 9 & 5 \\
\hline luteolin ${ }^{c}$ & + & 7 & 25 & + & 8 & 4 \\
\hline narnigenin & + & $\mathrm{n} / \mathrm{a}$ & 1 & + & $\mathrm{n} / \mathrm{a}$ & 1 \\
\hline quercetin ${ }^{c}$ & + & 11 & 13 & + & 2 & 1 \\
\hline rutin $^{c}$ & + & $\mathrm{n} / \mathrm{a}$ & 2 & + & $\mathrm{n} / \mathrm{a}$ & 1 \\
\hline tricin & + & 1 & 1 & + & 1 & 1 \\
\hline \multicolumn{7}{|l|}{ Carduus only } \\
\hline isorhamnetin & - & & & + & 1 & 1 \\
\hline tilianin & - & & & + & 1 & 1 \\
\hline total number of & lerivates & 65 & $\mathrm{n} / \mathrm{a}$ & & 29 & $\mathrm{n} / \mathrm{a}$ \\
\hline $\begin{array}{l}\text { total number of } \\
\text { studied }\end{array}$ & pecies & $\mathrm{n} / \mathrm{a}$ & $97^{d}$ & & $\mathrm{n} / \mathrm{a}$ & 12 \\
\hline
\end{tabular}

a Totals include the number of times that compound appeared in any of the species discussed in this review.

b See Tables 1 and 2 for references.

${ }^{\mathrm{c}}$ At least one derivative has insect bioactivity.

d North American native species totaled 13 out of the 92 Cirsium studied.

Carduus, we found evidence in the literature for compounds from only 12 species (Tables 2 \& 4) out of about 90+ species of Carduus worldwide (Bremer, 1994). No Carduus species are native to North America. The low proportion (13\%) of worldwide Carduus species that have been analyzed for their chemical profile is surprising. Two species, Carduus acanthoides and C. nutans, are considered major weeds worldwide (Frick, 1978; Delfosse, 2000; USDA Plant Database, 2002). Four of the 12 Carduus spp. studied chemically have been inadvertently introduced and naturalized in North America: Carduus acanthoides, C. nutans, C. pycnocephalus, and C. tenuiflorus (Tables 2 \& 4). 
Table 6. Species groups with shared chemical profiles by reported insect biologically active compounds ${ }^{\mathrm{a}}$

\begin{tabular}{|c|c|}
\hline \multicolumn{2}{|l|}{ Flavonoids } \\
\hline Apigenin & Luteolin \\
\hline Cirsium arvense ${ }^{c}$ & Cirsium amplexifolium \\
\hline Cir. canescens ${ }^{\mathrm{b}}$ & Cir. arvensec \\
\hline Cir. carolinianum & Cir. buergeri \\
\hline Cir. chikushiense & Cir. chikushiense \\
\hline Cir. drummondii ${ }^{\mathrm{b}}$ & Cir.echinus \\
\hline Cir. gratiosum & Cir. gyojanum \\
\hline Cir. japonicum & Cir. helenoides \\
\hline Cir. magofukui & Cir. hosogawa \\
\hline Cir. nipponicum & Cir. kawakamii \\
\hline Cir. oleraceum & Cir. lucens \\
\hline C. ochrocentrum ${ }^{\mathrm{b}}$ & Cir. magofukui \\
\hline Cir.purpuratum & Cir. matusmurae \\
\hline Cir. rhinoceros & Cir. matusmurae var. pubescens \\
\hline Cir. sieboldii & Cir. nipponicum var. yoshinoi \\
\hline Cir. syriacum & Cir. oleraceum \\
\hline Cir. vallis-demonii & Cir. palustre \\
\hline Cir. vulgare & Cir.pulcherrimum ${ }^{\mathrm{b}}$ \\
\hline Carduus assoic & Cir. rhinoceros \\
\hline Car. nutansc & Cir. seiboldi \\
\hline Car. pyncnocephalus ${ }^{\mathrm{c}}$ & Cir. suffultum \\
\hline \multirow[t]{3}{*}{ Car. tenuiflorus ${ }^{\mathrm{C}}$} & Cir. syriacum \\
\hline & Cir. tweedyib \\
\hline & Cir. vallis-demonii \\
\hline Vicenin-2 & Cir. wallichii \\
\hline Cirsium gratiosum & Cir. yakusimense \\
\hline \multirow[t]{2}{*}{ Cir. oligophyllum } & Carduus acanthoides ${ }^{\mathrm{c}}$ \\
\hline & Car. assoic \\
\hline Rutin & Car. gelulus ${ }^{\mathrm{c}}$ \\
\hline Cirsium gratiosum & Car. nutans ${ }^{c}$ \\
\hline \multicolumn{2}{|l|}{ Cir. arvense var. setosum } \\
\hline \multirow[t]{2}{*}{ Carduus nutans ${ }^{\mathrm{c}}$} & Skutellarein \\
\hline & Cirsium oleraceum \\
\hline \multicolumn{2}{|l|}{ Quercetin } \\
\hline Cirsium arvense ${ }^{c}$ & Cirsium subniveum ${ }^{\mathrm{b}}$ \\
\hline Cir. babanum & Cir. tioganum var. coloradense \\
\hline Cir. foliosum ${ }^{\mathrm{b}}$ & Cir. tweedyi $i^{\mathrm{b}}$ \\
\hline Cir. oleraceum & Cir. undulatum ${ }^{\mathrm{b}}$ \\
\hline Cir. pulcherrimum ${ }^{\mathrm{b}}$ & Cir.vallis-demonii \\
\hline Cir. scariosum ${ }^{\mathrm{b}}$ & Cir.vulgare, Carduus getulus ${ }^{\mathrm{c}}$ \\
\hline
\end{tabular}

(continued on next page)

In the genus Cirsium, we found evidence in the literature for compounds from 106 species worldwide (Tables 1 \& 3), even though at least 250 species of Cirsium have been described (Bremer, 1994). Only 16 of the 104 species (15.4\%) examined to date occur in North America, and only six of those $16(37.5 \%)$ are native to North America. Yet, at least 94 native Cirsium species and 125 accepted native taxa occur among the 100 species and 131 accepted taxa currently listed for the USA 
Table 6. (continued)

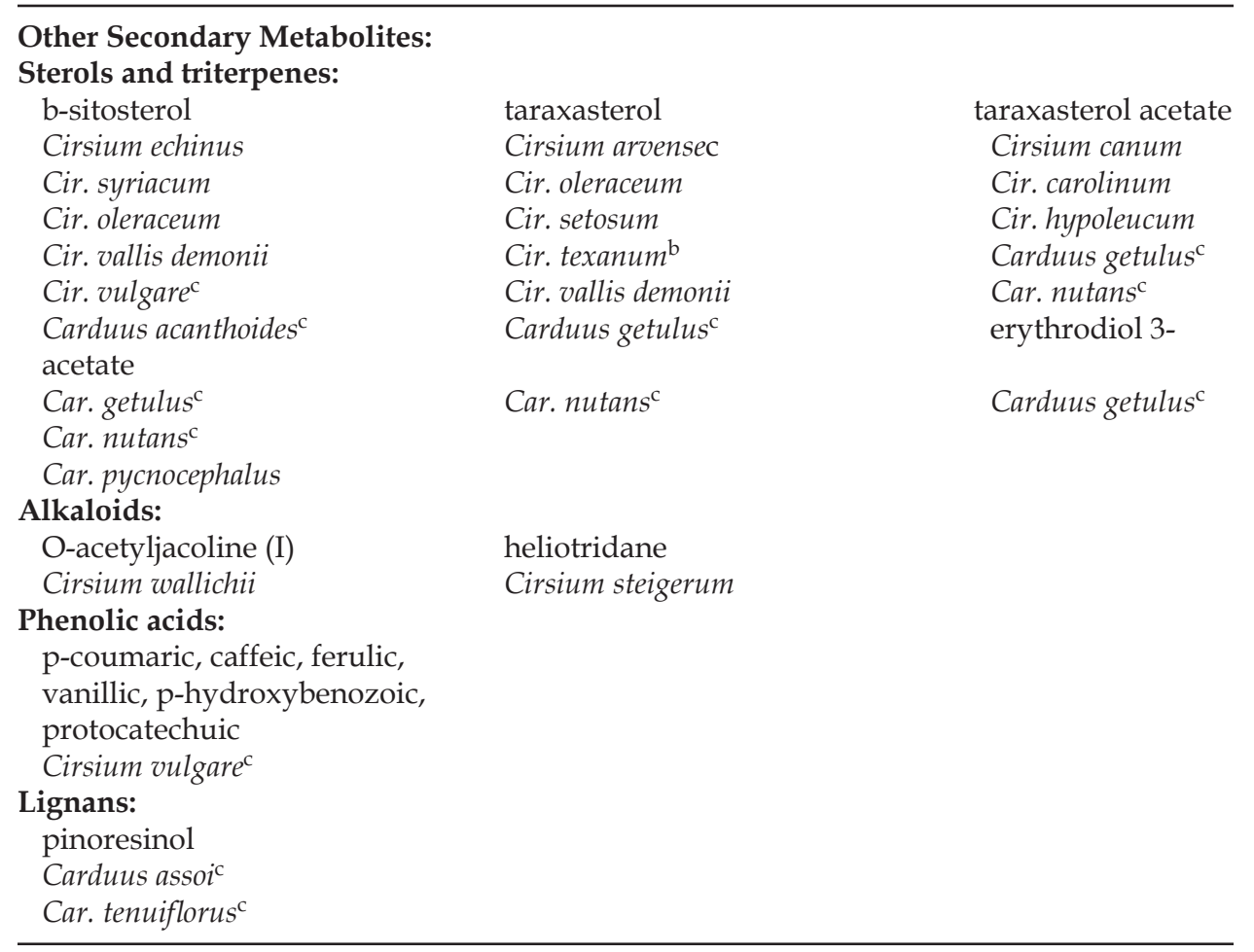

${ }^{a}$ References in Tables 1-4.

${ }^{\mathrm{b}}$ Native North American species.

${ }^{\mathrm{c}}$ Introduced North American species (Carduus is not native to North America).

(USDA Plant Database, 2002). Therefore, only 13.8\% of the native Cirsium spp., $10.4 \%$ of the accepted native taxa, and $16 \%$ of all species including exotics in the USA have been examined for their chemistry. Interestingly, the two native North American species for which the most compounds have been identified, Cirsium canescens and C. undulatum, are the same two species for which the most field evidence exists on non-target host selection by Rhinocyllus conicus (Rees, 1977, 1978; Louda et al., 1997; Louda, 1998, 1999b; Louda and Arnett, 2000).

\subsection{Missing data for sesquiterpene lactones?}

We were surprised by the scarcity of reports of sesquiterpene lactones in the 104 species of Cirsium and Carduus examined to date. We found only one report of these compounds for Cirsium or Carduus (Bohlmann and Abraham, 1981). Yet, these compounds often are common in the Asteraceae, including in close relatives of true thistles. For example, sesquiterpene lactones are common secondary metabolites in Centaurea and Cnicus, which are very close relatives (e.g. Bremer, 1994). Furthermore, these compounds significantly influence insect activity (above). There are two possible explanations for the apparent scarcity of 
Table 7. Flavonoids reported in Cirsium and Carduus species in Rhinocyllus case study ${ }^{\mathrm{a}}$

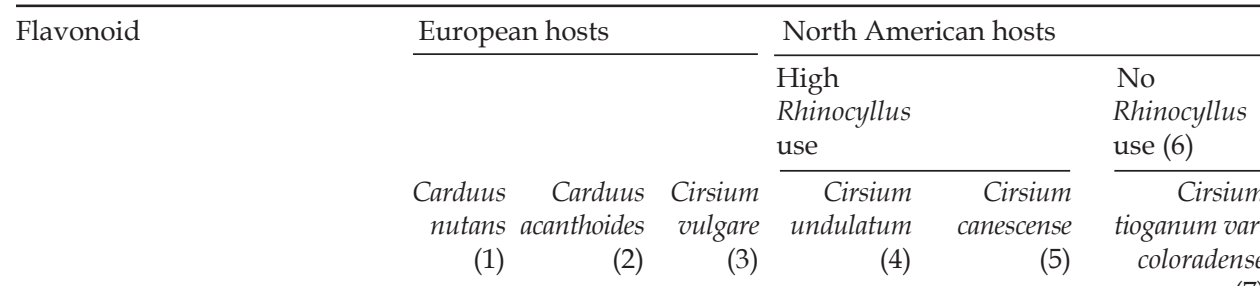

\begin{tabular}{|c|c|c|c|c|c|c|}
\hline apigenin & $\mathrm{X}$ & & & & & \\
\hline apigenin-6-8-C-diglycoside & & & & $x$ & $X$ & \\
\hline apigenin-7-O-diglucoside & & & $x$ & & $X$ & \\
\hline 6-methoxy apigenin-7-O-diglucoside & & & & & $X$ & \\
\hline apigenin-7-O-glucoside & $\mathrm{X}$ & & & & & \\
\hline apigenin-7-O-neohesperidoside & $X$ & & & $x$ & $X$ & \\
\hline chrysoerial-7-O-diglycoside & & & & & $X$ & \\
\hline $\begin{array}{l}\text { 6-methoxy chrysoerial-7-O- } \\
\text { diglucoside }\end{array}$ & & & & $x$ & & \\
\hline chrysoerial-7-O-monoglycoside & & & & $\mathrm{X}$ & & \\
\hline diosmetin-7-O-diglycoside & & & & & & \\
\hline genkwanin-4'-O-glucoside & & & $x$ & & & \\
\hline isorhamnetin & $\mathrm{X}$ & & & & & \\
\hline kaempferol & $X$ & & & & & \\
\hline kaempferol-3-O-arabinosylgalactose & & & $x$ & & & \\
\hline kaempferol-3-O-glucoside & & & $x$ & & & \\
\hline $\begin{array}{l}\text { kaempferol-3-O-glucoside-7-O- } \\
\text { rhamnoside }\end{array}$ & $\mathrm{X}$ & & & & & \\
\hline $\begin{array}{l}\text { kaempferol-3-O- } \alpha-\mathrm{L}- \\
\text { rhamnofuranoside }\end{array}$ & $\mathrm{X}$ & & & & & \\
\hline kaempferol-7-O-rhamnoside & $X$ & & & & & \\
\hline linarin & & & $?$ & $?$ & ? & $X$ \\
\hline 6-methoxy linarin & & & & & & $X$ \\
\hline luteolin & $\mathrm{X}$ & $X$ & $?$ & $?$ & $?$ & \\
\hline luteolin-7-O-galactoside & $x$ & $X$ & & & & \\
\hline luteolin-7-O-digalactoside & & $X$ & & & & \\
\hline luteolin-7-O-glucoside & $X$ & $X$ & & & & \\
\hline luteolin-7-O-diglucoside & $X$ & & & & & \\
\hline luteolin-7-O-rutinoside & $X$ & & & & & \\
\hline pectolinarin & & & $?$ & $?$ & $?$ & $X$ \\
\hline quercetin & $?$ & $?$ & & & $?$ & \\
\hline quercetin-3-O-diglycoside & & & & $x$ & & $X$ \\
\hline quercetin-3-O-galactose & & & $X$ & & & \\
\hline quercetin-3-O-glucose & & & $x$ & & & \\
\hline rutin & $X$ & & $x$ & $?$ & $?$ & \\
\hline tilianin & $X$ & & & & & \\
\hline
\end{tabular}


Table 7. (continued)

Key to Table 7 References (Numbers in parentheses):

1: Bain and Desrochers, 1988; Kaloshina and Mazulin, 1988; Abdellah et al., 1989

2: Frydman and Deulofeu, 1962; Nolasco et al., 1987; Bain and Desrochers, 1988

3: McGowan and Wallace, 1972; Wallace, 1974; Iwashina et al., 1995

4, 5: Gardner, 1974

6: Turner et al., 1987; Goeden and Ricker, 1987a

7: Gardner, 1973.

? = Literature suggests compound suspected to be found, but has not been found.

a Shown biological activity in insects.

sesquiterpene lactones reported from thistles. Either few of these compounds are present, or they have been missed in the general isolation protocols and not targeted for isolation with specifically suited procedures. Flavonoid analysis, the most common analysis reported here, relies mostly on polar and cellulosebased chromatography. The nonpolar sesquiterpene lactones are unlikely to be retained on this medium, and so are likely to have been discarded. We suggest that the prevalence of sesquiterpene lactones in other tribes of the Asteraceae (Hegnauer, 1977, 1989; Herz, 1977; Heywood et al., 1977; Seaman, 1982), the evidence of biological activity (above), and their presence in closely related species argue for direct studies of the presence or absence of sesquiterpene lactones in Cirsium and Carduus. Since specific methods for isolation of sesquiterpene lactones are well known (e.g. Bohlmann et al., 1984; Fernandez et al., 1989, 1995; Bicchi and Rubiolo, 1996), and since sesquiterpene lactones would be strong candidates to mediate host recognition and feeding by more specialized insects, we conclude that this lack of evidence presents an important opportunity for research.

\subsection{Potentially relevant variation in flavonoids}

Although the connection between plant flavonoid profile and insect behavior has been investigated, more research is needed (Rees and Harborne, 1985; Bohm, 1998; Simmonds, 2001). The evidence available strongly suggests that flavonoids could be important in thistle-insect interactions. Flavonoid occurrence and variation in thistles were well documented (Tables $1 \& 2$ ). Flavonoids were the most commonly reported compounds in thistles, providing $51.4 \%$ of the 212 total com- 
pounds reported from Cirsium and Carduus spp. For the flavonoids that have been recovered from these genera thus far, $71 \%$ of them were from Cirsium spp., compared to $28 \%$ from Carduus spp. To date, $44 \%$ of the flavonoid compounds reported from these genera have been tested for some form of biological activity, but only $13 \%$ for insect activity.

The similarities and differences in the flavonoid constituents of Cirsium and Carduus spp. may offer a useful starting point in searching for a chemical contribution to differential host preference. A group of flavonoid compounds were reported only from Cirsium spp., including pectolinarin, linarin, cirsimaritin, and acacetin. Alternatively, at least 12 flavonoid compounds were reported for both Cirsium and Carduus spp., including apigenin, chrysoeriol, diosmetin, hispidulin, kaempferol, luteolin, narnigenin, quercetin, rutin, and tricin (Table 5). Of the flavonoid compounds found, at least six are known to be biologically active towards insects: skutellarein, vicenin-2, apigenin, luteolin, quercetin, and rutin. Yet, flavonoid composition varied among species. Using such contrasts, one can infer that some of these compounds could be important in insect host choice (Table 6).

Variation in extraction protocols reported in the literature also suggests further investigation into flavonoid content is needed. For example, rutin (quercetin-3-O-rutinoside) may be found in other thistle species with additional effort. The inability of rutin to dissolve in non-polar solvents is due to its high polarity as a flavonol diglycoside. Thus, rutin is only partially soluble in alcoholic solvents, used to extract flavonoids. Rutin, therefore, often may be discarded with the extracted plant material before the diagnostic chromatography is begun (personal observation). Another possibility is that aglycosidic flavonoids that occur as plant exudates can be extracted by a quick second dip into a nonpolar solvent, such as acetone, and so may be discarded with the waxes and lipids (Bohm, 1998).

Many flavonoids have long been known as either antifeedants or stimulants on larvae and adults of various insects (Tables 1 \& 2). This knowledge has stimulated the investigation of the relationship between host plant flavonoid profile and insect behavior (Rees and Harborne, 1985; Bohm, 1998; Simmonds, 2001). For species of Cirsium and Carduus, the two main classes of flavonoids reported to exhibit biological activity towards insects are flavones and flavonols. These two groups of flavonoids are structurally similar, differing in only one alcohol group. Given the variation among flavonoids, which has proven to be distinctive among taxa (Bohm, 1998), and given their reported biological activity towards insects, analysis of flavonoid variation may provide an efficient initial approach to characterize profiles of thistle species relevant to their interactions with insects. Examination of the effect of mixtures of these compounds could also be productive, since a small difference of one or two compounds in a profile can make a marked difference in insect response (Berenbaum et al., 1991; Harborne, 1999), especially in relation to environmental variation (Louda and Rodman, 1983; Macedo and Langenheim, 1989; Louda and Collinge, 1992; Desrochers and Bohm, 1993; Cates, 1996). 


\subsection{Latex and exudates from Cirsium spp.}

The literature revealed groups of biologically active compounds associated with plant exudates from resin ducts, glandular trichomes, laticifers, and buds (Loomis and Croteau, 1973; Kelsey and Shafizadeh, 1980; Rossiter et al., 1986; Mauseth, 1988; Bramley, 1997; Wink, 1997; Ellis, 1997; Harborne, 1999). Many Cirsium species have glands on the involucral bracts (Great Plains Flora Association, 1986; Bremer, 1994). Also, many insects, including Rhinocyllus conicus, must feed on their host plants, prior to oviposition. Further, both vulnerable native thistle species in sand prairie (Cirsium canescens, C. undulatum) produce exudates from glandular ridges on bracts of their flower heads (personal observation). Together these observations suggest that characterization of the exudates of thistles would be productive.

\subsection{Methodological observations}

It became apparent that one of the main constraints on the current interpretation of the data available (Tables 1-4), similar to most meta-analyses, was that extraction and identification methods differed vastly among studies. Thus, articles that reported only a few compounds may not have screened the plant as intensively as those that reported more. Also the scarcity of sesquiterpene lactones in the literature on thistles may reflect methodological constraints (above). The implication for future work is that the plants of interest, such as invasive exotic weeds and potential non-target native host plants, need to be analyzed using a standardized protocol for extractions and chromatographic separations to determine comprehensively whether specific groups of potentially biologically active compounds are present. A primary goal should be to assure that all separations, from nonpolar to polar compounds, be equally analyzed. The continuing improvement in equipment and techniques for spectroscopic characterization suggests that structures may be more easily and accurately determined now (Eisner and Meinwald, 1995; Bohm, 1998) than traditionally (Mabry et al., 1970). Furthermore, determination of mixtures of compounds is becoming increasingly efficient.

\subsection{Application to Rhinocyllus conicus non-target host plant use}

The case that stimulated our question and literature survey was the report of varying use of non-target native North American thistles by the musk thistle biological control weevil $R$. conicus. In fact, the $R$. conicus case history provides a unique opportunity, given the field data now available on non-target host selection, to examine the potential for a role of chemical profile in host range expansion. Doing so should help improve the prediction of ecological impacts by exotic phytophagous insects in new environments. So, within the constraints of the data available, we compared known chemical profiles among three thistles that coevolved with $R$. conicus and three that did not (Table 7). The three coevolved Eurasian species were the two main Carduus spp. targeted for biological control, C. nutans and C. acanthoides (Frick, 1978), and the weevil's predominant host plant 
in maritime France, Cirsium vulgare (Zwölfer and Preiss, 1983; Briese, 1996). These three coevolved species varied in reported levels of $R$. conicus use. For example, Turner et al. (1987) found naturalized Cirsium vulgare (a European species) was heavily used in California: a rate of 0.03-0.24 adults, emerging from $17 \%$ of the heads sampled. The three native North American species, in order of their documented use by R. conicus were: C. canescens, C. undulatum, and C. tioganum var. coloradense (Turner et al., 1987; Goeden and Ricker, 1987a; Louda et al., 1997; Louda, 1998, 1999b; Louda and Arnett, 2000). The use by R. conicus of Cirsium canescens is high and higher than that of C. undulatum in native sand prairie of central USA (Louda et al., 1997, 1998; Louda, 1998, 1999b; Louda and Arnett, 2000). In California, Cirsium tioganum var. coloradense, however, had a very low Rhinocyllus conicus use rate: 0.1 heads per plant, in one of four populations studied (Turner et al., 1987), and Goeden and Ricker (1987b) did not find R. conicus on the C. tioganum var. coloradense plants they sampled.

Variation in flavonoids among these six taxa was species-specific (Table 7), reflecting the usefulness of flavonoids as a chemosystematic trait for analysis of evolutionary lineages (Bohm, 1998). The characterization and identification of flavonoids for the Cirsium spp., including the native North American thistles on which we have extensive field data (Platte [Cirsium canescens] and wavyleaf [C. undulatum] thistles), emerged from chemosystematic work (McGowan and Wallace, 1972; Gardner, 1973, 1974; Wallace, 1974; Iwashina et al., 1995). Such variation also provides a potential basis for host recognition, preference, and variation in insect performance (Harborne, 1999; Simmonds, 2001). The flavonoid profiles of the two main Carduus species (Carduus nutans, C. acanthoides) naturalized in the North America have also been determined (Frydman and Deulofeu, 1962; Nolasco et al., 1987; Abdallah et al., 1989; Bain and Desrochers, 1988; Kaloshina and Mazulin, 1988).

Interestingly, the two native Cirsium spp. and the two invasive Carduus spp. have both overlapping and distinctive flavonoids (Table 7). The data for C. vulgare and C. tioganum var. coloradense showed different profiles than those of $C$. canescens and C. undulatum (Table 7). The European Cirsium spp. did not have kaempferol or luteolin reported, although these two compounds have been found in many other Cirsium spp. (Table 5). Nor were pectolinarin and linarin reported. In our contrast, only Cirsium tioganum var. coloradense had these compounds, although they were very common in other Cirsium spp. None of the four reported flavonoids in Cirsium tioganum var. coloradense, the under-utilized North American species, were reported from the three coevolved European host plants (Table 7). Also, the more heavily damaged native species, Platte thistle (C. canescens), overlaps Carduus nutans for more flavonoids then does the other co-occurring native species, wavyleaf thistle (C. undulatum). Thus, the patterns of chemical variation are consistent with the prediction of higher use of C. canescens than of C. undulatum, as observed (Louda, 1998, 1999a; Louda and Arnett, 2000).

Sterols also varied among species. Sterols in Carduus nutans and C. acanthoides were not found in Cirsium undulatum, C. canescens, C. tioganum var. coloradense, or C. vulgare (Abdallah et al., 1989; Nolasco et al., 1987). This variation may contrib- 
ute to Rhinocyllus conicus general preference for Carduus over Cirsium spp. Carduus acanthoides also contained the alkaloids, acanthoidine, acanthoine and ruscopine, none of which have not been reported for the North American hosts and which could also play a role in host preference (Frydman and Deulofeu, 1962; Boidadzhiev, 1964).

Characterization of the chemical profile of the rare, federally listed Pitcher's thistle, Cirsium pitcheri, a close relative of Platte thistle, Cirsium canescens (Loveless and Hamrick, 1988) is not available. However, such data would provide information that would improve further the evaluation of the potential threat to the populations of this threatened rare species, should $R$. conicus disperse into its protected habitat (Louda et al., 2003c).

Given the reports to date, further analysis of chemical variation in vegetative tissues vs. in flowers is warranted to supplement what is known for these species to address the issue of host recognition, acceptance, and choice. Observations show that $R$. conicus often chooses potential host plants before flowering (anthesis) is initiated. Also, higher oviposition rates were correlated with feeding on leaf material (Louda and colleagues, unpublished data). Thus, we hypothesize that phagostimulatory and discriminatory compounds for $R$. conicus are likely to be within cell walls of the vegetative tissues. Candidate compound groups include flavonoids, sterols, triterpenes, lignans, and potentially sesquiterpene lactones, rather than the volatile components of flowers, for example. Also, based on the data reported in the literature, polyacetylenes, phenolic acids and alkaloids, most of which are reported primarily from the root systems, are less likely mediators of weevil host plant choice than flavonoids in this case. The probability that lignans play an important role in $R$. conicus host preference is not well supported by the present literature. More likely candidate compounds for phagostimulatory and discriminatory mediation of $R$. conicus host plant acceptance and preference appear to be flavonoids and sterols in the above-ground vegetative tissues.

Further information on chemical profiles and their variation should improve our understanding of mechanisms and vulnerabilities among closely related plant species to utilization by relatively stenophagous phytophagous insects, such as $R$. conicus, that are used in biological control of weeds. Thus, the Rhinocyllus conicus case history, along with the existing chemical and biological activity literature, suggests further examination of the role of flavonoids in host acceptance and preference of thistle-feeding insects is warranted. Their evaluation could contribute to improving prediction of potential ecological impacts of phytophagous insects in new environments.

\section{Conclusion}

From the literature on the chemistry of the main genera of the true thistles (Cirsium, Carduus), it is clear that multiple secondary metabolites are shared by species in these genera (Tables 1-4). Compounds that have already been shown to have biological activity towards insects are present in either Cirsium spp., or Car- 
duus spp., or both. Some of the compounds have a potential role in mediating the outcome of insect-plant interactions in the new environment in North America in the Rhinocyllus case study (Tables 5-7). In screening potential biological control agents for potential host range expansion, our review suggests secondary host plant chemistry provides a currently unexplored avenue for more precise evaluation of likely host range. Additionally, our findings are consistent with the suggestions of Becerra and Venable (1999) that host chemistry may be more important to beetle host preference than close phylogenetic relationship or geographic region of origin. Since the aim of screening tests for biological control agents is to predict the risk of host range expansion and ecological impact in the new region, and since current host specificity testing can fall short of doing so (Arnett and Louda, 2002), additional chemical data should be useful (Harborne, 1991; Simmonds, 2001). Our review suggests that consideration of contemporary chemical profiles to supplement host specificity tests based on phylogenetic relationships will contribute to a clearer prediction of potential host plant use and ecological impacts.

\section{Acknowledgments}

We would like to acknowledge and thank Patrick H. Dussault, University of NebraskaLincoln Department of Chemistry, for encouragement, guidance, and involvement in the initial project design; and Anurag Agrawal, Ragan M. Callaway, Peter Houghton, Mark D. Hunter, Steve K. Jordon, Robert B. Kaul, Thomas E. Miller, Rodney W. Otley, Binney O. Phinney, and Tatyana A. Rand for input at various stages of this research. The project could not have been done without the lifelong support and encouragement for I.E.J.-T. by Helen, Steve, and Leland Jordon as well as by Brandon Jordon-Thaden, all of whom facilitated the research in innumerable and critical ways. Partial support was provided by an R.E.U. supplement from The National Science Foundation to S.M.L. (DEB9616210).

\section{References}

Abdallah et al., 1989 O. M. Abdallah, M. A. Ramadan, and M. A. El-Shanawany, Phytochemical study of Carduus nutans L. (Asteraceae). Bull Fac Aci, Assiut Univ 182 (1989), pp. 69-76 CA 114:182015 .

Abdel-Salam et al., 1982 N. A. Abdel-Salam, Z. F. Mahmond, R. Abdel-Hamid, and S. M. Khafagy, The flavonoid, steroid and triterpenoid constituents of Carduus getulus Pomel (Compositae). Egypt J Pharm Sci 23 1-4 (1982), pp. 199-202 CA 102:75713.

Abdel-Salam et al., $1983 \rightarrow$ N. A. Abdel-Salam, I. Morelli, and S. Catalano, An unusual triterpene ester in a Compositaceous plant, Carduus getulus Pomel. International Journal of Crude Drug Research 212 (1983), pp. 79-80.

Alder, $1995 \rightarrow$ G. Alder, Biosynthesis and distribution of insect-molting hormones in plants - A review. Lipids 305 (1995), pp. 257-262.

Amer et al., 1985 M. M. A. Amer, O. M. Salama and A. A. Omar, Flavonoids of Carduus pycnocephalus. Fitoterapia 561 (1985), p. 61.

Andronescu et al., $1984 \longrightarrow$ E. Andronescu, P. Petcu, E. Bordas, S. Barbu, and A. Zeic, Total extract of Cnicus benedictus. Institutul de Medicina si Farmacie, Rom 2 (1984).

Aquino et al., $1987 \rightarrow$ R. Aquino, I. Behar, F. D. Simone, and F. Menichini, Preliminary investigation on Cirsium vallis demonii. Fitoterapia 586 (1987), pp. 428-429 CA 103:27279.

Arnason et al., 1987 J. T. Arnason, M. B. Isman, B. J. R. Philogene, and T. G. Waddell, Mode of action of the sesquiterpene lactone, tenulin, from Helenium amarum against herbivorous insects. Journal of Natural Products 504 (1987), pp. 690-695. 
Arnason et al., 1981 J. T. Arnason, T. Swain, C. K. Wat, E. A. Graham, S. Partington, G. H. N. Towers, and J. Lam, Mosquito larvicidal activity of polyacetylenes from species in the Asteraceae. Biochemical Systematics and Ecology 91 (1981), pp. 63-68.

Arnett and Louda, 2002 A. E. Arnett and S. M. Louda, Re-test of Rhinocyllus conicus host specificity, and the prediction of ecological risk in biological control. Biological Conservation 106 (2002), pp. 251-257.

Baek et al., 1995 N. Baek, J. D. Park, Y. H. Lee, S. Y. Jeong, and S. I. Kim, A novel polyacetylene from Cirsium spp. Yakhak Hoeji 393 (1995), pp. 268-275 CA 123:138799.

Bain and Desrochers, 1988 J. F. Bain and A. M. Desrochers, Flavonoids of Carduus nutans and C. acanthoides. Biochemical Systematics and Ecology 163 (1988), pp. 265-268.

Becerra, 1997 J. X. Becerra, Insects on plants, macroevolutionary chemical trends in host use. Science 276 (1997), pp. 253-256 April 11.

Becerra and Venable, $1999-$ J. X. Becerra and L. D. Venable, Macroevolution of insect-plant associations, the relevance of host biogeography to host affiliation. PNAS 9622 (1999), pp. 12626-12631.

Benayache et al., 1992 F. Benayache, S. Benayache, K. Medjroubi, G. Massiot, P. Aclinou, B. Drodz, and G. Nowaks, Sesquiterpene lactones from Centaurea pullata. Phytochemistry 3112 (1992), pp. 4359-4360.

Berenbaum, 1995 M. R. Berenbaum, The chemistry of defense, theory and practice. PNAS USA 92 (1995), pp. 2-8.

Berenbaum et al., $1991>$ M. Berenbaum, J. K. Nitao, and A. R. Zangerl, Adaptive significance of furanocoumarin diversity in Pastinaca sativa, Apiaceae. Journal of Chemical Ecology 17 (1991), p. 207.

Berenbaum and Zangerl, 1988 M. R. Berenbaum and A. R. Zangerl, Stalemates in the coevolutionary arms race. In: K. C. Spencer, ed., Syntheses, Synergisms, and Sundry Other Sins, Academic Press, San Diego (1988), pp. 113-132.

Bernays and Chapman, 1994 E. A. Bernays and R. F. Chapman, Host Selection by Phytophagous Insects, Chapman \& Hall, London (1994).

Bicchi and Rubiolo, 1996 C. Bicchi and P. Rubiolo, High-performance liquid chromatographic-particle beam mass spectrometric analysis of sesquiterpene lactones with different carbon skeletons. Journal of Chromatography A 727 (1996), pp. 211-221.

Binder et al., 1992 R. G. Binder, M. Benson, W. F. Haddon, and R. C. French, Aplotaxene derivatives from Cirsium arvense. Phytochemistry 313 (1992), pp. 1033-1034.

Binder and French, $1994 \rightarrow$ R. G. Binder and R. C. French, Volatile components of Canada thistle. Journal of Agricultural Food Chemistry 42 (1994), pp. 2942-2945.

Bohlmann and Abraham, 1981 F. Bohlmann and W. Abraham, Aplotaxene epoxide from Cirsium hypoleucum. Phytochemistry 204 (1981), pp. 855-856.

Bohlmann et al., 1973 F. Bohlmann, T. Burkhardt, and C. Zdero, Naturally Occurring Acetylenes, Academic Press, London (1973).

Bohlmann et al., 1984 F. Bohlmann, C. Zdero, R. M. King, and H. Robinson, Pseudoguaianolides and other sesquiterpene lactones from Gaillardia species. Phytochemistry 239 (1984), pp. 1979-1988.

Bohm, 1998 B. A. Bohm, Introduction to Flavonoids, Australia, Harwood Academic Publishers (1998).

Boidadzhiev, 1964 T. Boidadzhiev, Experimental Study of the Hypotensive Effect of Carduus acanthoides Preparations, Nauchni Trudove Na Visshiia Meditsinski Institut, Sofiia (1964) 4337-44.

Bramley, 1997 P. M. Bramley, Isoprenoid metabolism. In: P. M. Dey and J. B. Harborne, eds., Plant Biochemistry, Academic Press, San Diego (1997), pp. 417-434.

Bremer, 1994 K. Bremer, Asteraceae, Cladistics and Classification, Timber Press, Portland, OR (1994).

Briese, 1996 D. T. Briese, Phylogeny: can it help us to understand host choice by biological wed control agents? In: V. C. Moran and J. H. Hoffman, eds., Proceedings of the IX International Symposium on Biological Control of Weeds, University of Cape Town, South Africa (1996), pp. 63-70.

Burnett and Jones, $1974 \longrightarrow$ W. C. Burnett and S. B. Jones, Sesquiterpene lactones - Insect feeding deterrents in Vernonia. Biochemical Systematics and Ecology 2 (1974), pp. 25-29.

Cabral et al., 2000 M. M. O. Cabral, P. Azambuja, O. R. Gottlieb, and E. S. Garcia, Effects of some lignans and neolignans on the development and excretion of Rhodnus prolixus. Fitoterapia 711 (2000), pp. 1-9.

Cabral et al., 1999 M. M. O. Cabral, A. Kelecom, and E. S. Garcia, Effects of the lignan, pinoresinol on the molting cycle of the bloodsucking bug Rhodnius prolixus and of the milkweed bug Oncopeltus fasciatus. Fitoterapia 706 (1999), pp. 561-567.

Carde and Bell, $1995 \rightarrow$ R. T. Carde and W. J. Bell, Chemical Ecology of Insects, Chapman and Hall, London (1995).

Callaway et al., $1999>$ R. M. Callaway, T. H. DeLuca, and W. M. Welliveau, Biological-control herbivores may increase competitive ability of the noxious weed Centaurea maculosa. Ecology 804 (1999), pp. 1196-1201. 
Cardona et al., 1992a $>$ L. Cardona, I. Fernandez, J. R. Pedro, and R. Vidal, Polyoxygenated terpenes and cyanogenic glucosides from Centaurea aspera var. subinermis. Phytochemistry 3110 (1992), pp. 3507-3509.

Cardona et al., 1992b - L. Cardona, B. Garcia, J. R. Pedro, and J. Perez, 6-Prenyloxy-7-methoxycoumarin, a coumarin-hemiterpene ether from Carduus tenuiflorus. Phytochemistry 3111 (1992), pp. 3989-3991.

Cates, 1996 R. G. Cates, The role of mixtures and variation in the production of terpenoids in coniferinsect-pathogen interactions. In: J. T. Romeo, J. A. Saunders and P. Barbosa, eds., Recent Advances in Phytochemistry, Vol 30, Phytochemical Diversity and Redundancy in Ecological Interactions, Plenum Press, New York (1996), pp. 179-216.

Christensen, 1992 L. P. Christensen, Aplotaxene Derivatives from Cirsium heleniodies. Phytochemistry 316 (1992), pp. 2039-2041.

Classen et al., 1990 D. Classen, J. T. Arnason, J. A. Serratos, J. D. H. Lambert, C. Nozzolillo, and B. J. R. Philogene, Correlation of phenolic acid content of maize to resistance to Sitophilus zeamais, the maize weevil, in CIMMYT's collections. Journal of Chemical Ecology 162 (1990), pp. 301-315.

Courtney and Kibota, 1990 S. P. Courtney and T. T. Kibota, Mother doesn't know best. Selection of hosts by ovipositing insects. In: E. A. Bernays, Ed., Plant-Insect Relationships, CRC Press (1990).

Darvas, 1991 B. Darvas, Phytoecdysteroids of Ajuga species, botanical insecticides with insect growth regulator activity. Novenyvedelem 27 11-12 (1991), pp. 481-498 CA 117:42567 .

DeBach and Rosen, 1991 P. DeBach and D. Rosen, Biological Control by Natural Enemies, Cambridge University Press (1991).

Delfosse, 2000 E. S. Delfosse, Biological control, important tool for managing invasive species. Agricultural Research 48 (2000), p. 2.

Desrochers and Bohm, 1993 A. M. Desrochers and B. A. Bohm, Flavonoid variation in Lasthenia californica (Asteraceae). Biochemical Systematics and Ecology 214 (1993), pp. 449-453.

Dethier, 1947 V. G. Dethier, Chemical Insect Attractants and Repellents, The Bakiston Company, Philadelphia (1947).

Dittrich, 1977 M. Dittrich, Cynareae, Systematic review. In: V. H. H. J. Heywood, ed., The Biology and Chemistry of the Compositae, Academic Press, London (1977), pp. 999-1015.

Do et al., 1994 J. C. Do, K. Y. Jung, and K. H. Son, Isolation of pectolinarin from the aerial parts of Cirsium nipponicum. Saengyak Hakhoe Chi 251 (1994), pp. 73-75 CA 121:104074 .

Dominguez et al., 1974 X. A. Dominguez, A. Gonzalez, A. Zamudio, and A. Garza, Taraxasterol from Stevia berlandieri and Cirsium texanum. Phytochemistry 13 (1974), p. 2001.

Dugassa-Gobena et al., 1998 D. Dugassa-Gobena, A. Raps, and S. Vidal. Influence of fungal endophytes on allelochemicals of their host plants and the behavior of insects. Institute for Plant Diseases and Plant Protection, University of Hannover, Germany. 63 (2a), 333-337. (1998)

Dutta et al., 1972 C. P. Dutta, L. P. K. Ray, and D. N. Roy, Taraxasterol and its derivatives from Cirsium arvense. Phytochemistry 11 (1972), pp. 2267-2269.

Ehrlich and Raven, $1964 \rightarrow$ P. R. Ehrlich and P. H. Raven, Butterflies and plants. A study in coevolution. Evolution 18 (1964), pp. 586-608.

Eisner and Meinwald, 1995 T. Eisner and J. Meinwald, Chemical Ecology, The Chemistry of Biotic Interaction, National Academy Press, Washington, DC (1995).

El-Lakany et al., 1995 A. M. El-Lakany, M. S. Abdel-Kader, H. M. Hammoda, N. M. Ghazy, and Z. F. Mahmoud, Flavonoids from Carduus pycnocephalus L. Alexandria. Journal of Pharmaceutical Sciences 91 (1995), pp. 41-43.

El-Lakany et al., 1997 A. M. El-Lakany, M. S. Abdel-Kader, H. M. Hammoda, N. M. Ghazy, and Z. F. Mahmoud, A new flavone glycoside with antimicrobial activity from Carduus pycnocephalus L. Pharmazie 521 (1997), pp. 78-79.

Elliger et al., $1980>$ C. A. Elliger, B. C. Chan, and A. C. Waiss, Jr., Flavonoids as larval growth inhibitors. Structural factors governing toxicity. Naturwissenschaften 67 (1980), pp. 358-360 CA 93: 126330 .

Ellis, 1997 B. E. Ellis, Metabolism of defence and communication. In: D. T. Dennis, D. H. Turpin, D. D. Lefebvre and D. B. Layzell, eds., Plant Metabolism, 2nd edition, Longman, Singapore (1997), pp. 148-160.

Eskelesen and Crabtree, $1995 \rightarrow$ S. R. Eskelesen and G. D. Crabtree, The role of allelopathy in buckwheat (Fagopyrum sagittatum) inhibition of Canada Thistle (Cirsium arvense). Weed Science 43 (1995), pp. 70-74.

Espinosa-Garcia and Langenheim, 1991 F. J. Espinosa-Garcia and J. H. Langenheim, Effects of sabinene and g-t erpinene from coastal redwood leaves acting singly or in mixtures on the growth of some of their fungus endophytes. Biochemical Systematics and Ecology 198 (1991), pp. 643-650. 
Feeny et al., 1988 P. Feeny, K. Sachedev, L. Rosenberry, and M. Carter, Luteolin 1-O-(6"-O-malonyl)-BD-glucside and trans-chlorogenic acid, ovipositon stimulants for the black swallowtail butterfly. Phytochemistry 2711 (1988), pp. 3439-3448.

Feldlaufer and Svoboda, 1988 M. F. Feldlaufer and J. A. Svoboda, Sterol metabolism and utilization in insects. Animal and Plant Science 11 (1988), pp. 9-14.

Fernandez et al., 1989 I. Fernandez, B. Garcia, F. J. Grancha, and J. R. Pedro, Sesquiterpene lactones, flavonoids and coumarins from Centaurea collina. Phytochemistry 289 (1989), pp. 2405-2407.

Fernandez et al., 1991 I. Fernandez, B. Garcia, J. R. Pedro, and A. Varea, Lignans and flavonoids from Carduus assoi. Phytochemistry 303 (1991), pp. 1030-1032.

Fernandez et al., 1995 I. Fernandez, J. R. Pedro, and E. Polo, Sesquiterpene lactones from Centaurea alba and C. conifera. Phytochemistry 383 (1995), pp. 655-657.

Fischer et al., $1990>$ D. C. Fischer, M. Kogan, and J. Paxton, Deterrency of Mexican bean beetle (Coleoptera, Coccinellidae) feeding by free phenolic acids. Journal of Entomological Science 252 (1990), pp. 230-238.

French, 1990 R. C. French, Stimulation of germination of teliospores of Puccinia punctiformis by nonyl, decyl, and dodecyl isothiocyanates and related volatile compounds. Journal of Agricultual and Food Chemistry 38 (1990), pp. 1604-1607.

French et al., $1994 \rightarrow$ R. C. French, S. E. Nester, and R. G. Binder, Volatiles from germinating Canada thistle seed and root cuttings that stimulate germination of teliospores of the Canada thistle rust, Puccinia punctiformis. Journal of Agricultual and Food Chemistry 4212 (1994), pp. 2937-2941.

French et al., $1988 \triangleright$ F. C. French, S. K. Turner, P. E. Sonnett, P. Pfeffer, and E. Piotrowski, Properties of an extract from Canada thistle roots that stimulates germination of dormant teliospores of Canada thistle rust (Puccinia punctiformis). Journal of Agricultual and Food Chemistry 365 (1988), pp. 1043-1047.

Frick, $1978 \triangleright$ K. E. Frick. Biological control of thistles in the genus Carduus in the United States. A progress report. Science and Education Administration and US Department of Agriculture, New Orleans, LA (1978).

Frydman and Deulofeu, 1962 B. Frydman and V. Deulofeu, Studies on Argentina plants - XIX Alkaloids from Carduus acanthoides L. structure of acanthoine and acanthoidine and synthesis of racemic acanthoidine. Tetrahedron 18 (1962), pp. 1063-1072.

Futuyma, 1983 D. J. Futuyma, Selective factors in the evolution of host choice by phytophagous insects. In: S. Ahmad, ed., Herbivorous Insects, Host-Seeking Behavior and Mechanisms, Academic Press (1983), pp. 227-244.

Gardner, 1973 R. C. Gardner, Acacetin-7-O-rutinoside and pectolinarin from Cirsium coloradense. Phytochemistry 12 (1973), p. 223.

Gardner, 1974 R. C. Gardner, Systematics of Cirsium (Compositae) in Wyoming. Madrono 22 (1974), pp. 239-265.

Gassmann and Louda, 2001 A. Gassmann and S. M. Louda, initial evaluation and subsequent ecological impacts in North America. In: E. Wajnberg, J. K. Scott and P. C. Quimby, eds., Evaluating Indirect Ecological Effects of Biological Control, CABI Publishing (2001), pp. 147-183.

Gershenzon and Croteau, 1991 J. Gershenzon and R. Croteau, Terpenoids. In: G. A. Rosenthal and M. Berenbaum, eds., Herbivores, Their Interactions with Secondary Metabolites, 2 nd edn, vol. 1, The Chemical Participants, Academic Press, San Diego (1991), pp. 165-209.

Glyzinm et al., 1977 V. I. Glyzinm, V. L. Shelyuto, A. V. Patudin, and N. T. Bubon, Flavonoids of Cirsium Mill species. Mater S'ezde Farm B SSR (1977), pp. 153-156 CA 92:124873 .

Goeden and Ricker, 1986a $>$ R. D. Goeden and D. W. Ricker, Phytophagous insect faunas of the two most common native Cirsium thistles, C. californicum and C. proteanum, in southern California. Annals of the Entomological Society of America 79 (1986), pp. 953-962.

Goeden and Ricker, 1986b R. D. Goeden and D. W. Ricker, Phytophagous insect faunas of two introduced Cirsium thistles, C. ochrocentrum and C. vulgare, in southern California. Annals of the Entomological Society of America 79 (1986), pp. 945-952.

Goeden and Ricker, 1987a R. D. Goeden and D. W. Ricker, Phytophagous insect faunas of native Cirsium thistles, C. mohavense, C. neomexicanum, and C. nidulum, in the Mojave Desert of southern California. Annals of the Entomological Society of America 80 (1987), pp. 161-175.

Goeden and Ricker, 1987b $>$ R. D. Goeden and D. W. Ricker, Phytophagous insect faunas of the native thistles, Cirsium brevistylum, Cirsium congdonii, Cirsium occidentale and Cirsium tioganum in southern California. Annals of the Entomological Society of America 80 (1987), pp. 152-160.

Gordaliza et al., $2000>$ M. Gordaliza, M. A. Castro, J. M. M. Del Corral, and A. S. Feliciano, Antitumor properties of podophyllotoxin and related compounds. Current Pharmaceutical Design 618 (2000), pp. 1811-1839 CA 134:157107 . 
Great Plains Flora Association, 1986 Great Plains Flora Association. Flora of the Great Plains. University Press of Kansas Lawrence, Kansas (1986).

Gross, 1981 G. G. Gross, Phenolic acids. In: E. E. Conn, ed., The Biochemistry of Plants, A Comprehensive Treatise, vol. 7. Secondary Plant Products, Academic Press, New York (1981), pp. 301-316.

Guillet et al., $1997 \rightarrow$ G. Guillet, B. J. R. Philogene, J. O'Meara, T. Durst, and J. T. Arnason, Multiple modes of insecticidal action of three classes of polyacetylene derivatives from Rudbeckia hirta. Phytochemistry 463 (1997), pp. 495-498.

Harborne, 1967 J. B. Harborne, Comparative Biochemistry of the Flavonoids, Academic Press, New York (1967).

Harborne, 1977 J. B. Harborne, Flavonoid profiles in the compositae. In: V. H. Heywood, J. B. Harborne and B. L. Turner, eds., The Biology and Chemistry of the Compositae, Academic Press, London (1977), pp. 359-384.

Harborne, 1990 J. B. Harborne, Role of secondary metabolites in chemical defense mechanisms in plants. In: Bioactive Compounds from Plants, John Wiley and Sons, Chichester (1990), pp. 126-139.

Harborne, 1991 J. B. Harborne, Flavonoid pigments. In: G. Rosenthal and M. R. Berenbaum, eds., Herbivores, Their Interactions with Secondary Metabolites, 2 edn, Academic Press, San Diego (1991), pp. 389-429.

Harborne, 1993 J. B. Harborne, Introduction to Ecological Biochemistry, Academic Press, London (1993).

Harborne, 1999 J. B. Harborne, Classes and functions of secondary products from plants. In: N. J. Walton and D. E. Brown, eds., Chemicals from Plants, Perspectives on Plant Secondary Products, Imperial College Press, London (1999), pp. 1-26.

Harborne et al., 1999 - J. B. Harborne, H. Baxter, and G. P. Moss, Phytochemical Dictionary, A Handbook of Bioactive Compounds from Plants, 2nd edn., Taylor and Francis, London (1999).

Haribal and Renwick, 1996 M. Haribal and J. A. A. Renwick, Oviposition stimulants for the monarch butterfly, Flavonol glycosides from Asclepias curassavica. Phytochemistry 411 (1996), pp. 139-144.

Harmatha and Nawrot, $1984 \rightarrow$ J. Harmatha and J. Nawrot, Comparison of the feeding deterrant activity of some sesquiterpene lactones and a lignin lactone towards selected insect storage pests. Biochemical Systematics and Ecology 121 (1984), pp. 95-98.

Hedin et al., $1968 \rightarrow$ P. A. Hedin, L. R. Miles, and A. C. Thompson, Constituents of the cotton bud. Formulation of a boll weevil feeding stimulant mixture. Journal of Agricultural and Food Chemistry 16 (1968), p. 505.

Hedin and Waage, 1986 P. A. Hedin and S. K. Waage, Roles of flavonoids in plant resistance to insects. In: V. Cody, E. Middleton and J. B. Harborne, eds., Plant Flavonoids in Biology and Medicine, Biochemical, Pharmacological, and Structure-Activity Relationships, Alan R. Liss, New York (1986), pp. 87-100.

Hegnauer, $1977-$ R. Hegnauer, The chemistry of the Compositae. In: V. H. Heywood, J. B. Harborne and B. L. Turner, eds., The Biology and Chemistry of the Compositae, Academic Press, London (1977), pp. 283-335.

Hegnauer, 1989 R. Hegnauer, Chemotaxonomie der Pflanzen, Birkhauser Verlag, Basel (1989).

Herr, 2000 J. C. Herr, Evaluating non-target effects, the thistle story. In: Proceedings of the California Conference on Biological Control II, (2000).

Herz, 1977 W. Herz, Sesquiterpene lactones in the compositae. In: V. H. Heywood, J. B. Harborne and B. L. Turner, eds., The Biology and Chemistry of the Compositae, Academic Press, London (1977), pp. 337-357.

Heywood et al., $1977 \vee$ V. H. Heywood, J. B. Harborne, and B. L. Turner, The Biology and Chemistry of the Compositae, Vol. 1, Academic Press, London (1977).

Howarth, 1991 - F. G. Howarth, Environmental impacts of classical biological control. Annual Review of Entomology 36 (1991), pp. 485-509.

Ismailov, $1958-\mathrm{N}$. M. Ismailov, Alkaloid containing plants from the Khaldan and Agdash regions. Izvest Akad Nauk Azerbidzhan SSR Ser Biol i Sel'skokhoz Nauk 411 (1958) CA 53:19470 .

Iwashina et al., 1995 T. Iwashina, Y. Kadota, T. Ueno, and S. Ootani, Foliar flavonoid composition in Japanese Cirsium species (Compositae), and their chemotaxonomic significance. The Journal of Japanese Botany 705 (1995), pp. 280-290.

Iwashina et al., 1999 - T. Iwashina, K. Kamenosono, and T. Ueno, Hispidulin and nepetin 4'-glucosides from Cirsium oligophyllum. Phytochemistry 51 (1999), pp. 1109-1111.

Kaloshina and Mazulin, 1988 N. A. Kaloshina and A. V. Mazulin, Flavonoids of Carduus nutans. Khimiya Prirodnykh Soedinenii 3453 (1988) CA 109:208312.

Kaneta et al., 1978 M. Kaneta, H. Hikichi, S. Endo, and N. Sugiyama, Identification of flavones in sixteen Compositae species. Journal of Agricultual and Biological Chemistry 422 (1978), pp. 475-477. 
Kataria, 1995 H. C. Kataria, Phytochemical investigation of medicinal plants Cnicus wallichii and Cnicus benedictus L. Asian J Chem 71 (1995), pp. 227-228.

Kelsey and Shafizadeh, 1980 R. G. Kelsey and F. Shafizadeh, Glandular trichomes and sesquiterpene lactones of Artemisia nova (Asteraceae). Biochemical Systematics and Ecology 8 (1980), pp. 371-377.

Khafagy et al., $1981>$ S. M. Khafagy, A. F. Halim and A. A. Gohar, Chemical study of Cirsium syriacum. Fitoterapia 521 (1981), pp. 21-23.

Kim et al., 2000 J. -S. Kim, C. -S. Kwon, and K. H. Son, Inhibition of a-glucosidase and a-amylase by Luteolin, a flavonoid. Bioscience, Biotechnology, and Biochemistry 6411 (2000), pp. 2458-2461.

Krzysztofik and Ludwiczak, $1970 \rightarrow$ B. Krzysztofik and R. S. Ludwiczak, Triterpenes and sterols of Cirsium olaraceum. Herba Hungarica 92 (1970), pp. 99-104 CA 75:72530 .

Lajide et al., 1995 - L. Lajide, P. Escoubas, and J. Mizutani, Termite antifeedant activity from tropical plants. Part 1. Termite antifeedant activity in Xylopia aethiopica. Phytochemistry 404 (1995), pp. 1105-1112.

Landau et al., 1994 I. Landau, H. Muller-Scharer, and P. I. Ward, Influence of cnicin, a sesquiterpene lactone of Centaurea maculosa (Asteraceae), on specialist and generalist insect herbivores. Journal of Chemical Ecology 204 (1994), pp. 929-942.

Lee et al., 1994 H. B. Lee, J. H. Kwak, O. P. Zee, and S. J. Yoo, Flavonoids from Cirsium rhinoceros. Archives Pharmacal Research 174 (1994), pp. 273-277 CA 122:27693.

Lege et al., $1995>$ K. E. Lege, J. T. Cothren, and C. W. Smith, Phenolic acid and condensed tannin concentration of six cotton genotypes. Environmental and Experimental Botany 352 (1995), pp. 241-249.

Lim et al., 1997 S. Lim, J. -H. Lee, and J. -C. Park, Isolation of flavone glycoside from Cirsium japonicum var ussuriense and biological activity on the cardiovascular system. Han'guk Sikp'um Yongyang Kwahak Hoechi 262 (1997), pp. 242-247 CA 127:92704.

Lin, 1975 C. N. Lin, Components of Formosan Cirsium species. III. Flavonoids of Cirsium kawakamii and Cirsium wallichii. Journal of the Chinese Chemical Society (Taipei-Taiwan) 223 (1975), pp. 275-277 CA $84: 28055$

Lin et al., $1978>$ C. -N. Lin, M. Arisawa, M. Shimizu, and N. Morita, Studies on the constituents of Formosan Cirsium species Part V. The constituents of Cirsium japonicum D. C. var takaoense Kitamura, isolation of two new flavonoids, cirsitakaoside (IV) and cirsitakaogenin (VI). Chemical and Pharmaceutical Bulletin 267 (1978), pp. 2036-2039 CA 89:160111.

Lin et al., 1975 C. -N. Lin, C. -H. Chang, and T. -S. Wu, Studies on the components of Formosa Cirsium species. Part II Components of Cirsium arisanense. Kitam (1975).

Locken and Kelsey, 1987 L. J. Locken and R. G. Kelsey, Cnicin concentrations in Centaurea maculosa, Spotted Knapweed. Biochemical Systematics and Ecology 153 (1987), pp. 313-320.

Loomis and Croteau, $1973 \rightarrow$ W. D. Loomis and R. Croteau, Biochemistry and physiology of lower terpenoids. In: C. Runeckles and T. J. Mabry, eds., Recent Advances in Phytochemistry: Terponoids: Structure, Biogenesis, and Distribution, Vol. 6 (1973), pp. 147-185.

Louda, 1998 S. M. Louda, Population growth of Rhinocyllus conicus (Coleoptera, Curculionidae) on two species of native thistles in prairie. Environmental Entomology 274 (1998), pp. 834-841.

Louda, 1999a $\backslash$ S. M. Louda, Ecology of interactions needed in biological control practice and policy. Bulletin of the British Ecological Society 29 (1999), pp. 8-11.

Louda, 1999b S. M. Louda, Negative ecological effects of the musk thistle biocontrol agent, Rhinocyllus conicus Fröl. In: P. A. Follet and J. J. Duan, eds., Nontarget Effects of Biological Control, Kluwer Academic Publishers (1999), pp. 215-243.

Louda and Arnett, $2000>$ S. M. Louda and A. E. Arnett, Predicting non-target ecological effects of biological control agents, Evidence from Rhinocyllus conicus. In: N. R. Spencer, ed., Proceedings of the 10th International Symposium on the Biological Control of Weeds, Montana State University (2000), pp. 551-567.

Louda and Collinge, 1992 S. M. Louda and S. K. Collinge, Plant resistance to insect herbivores, A field test of the environmental stress hypothesis. Ecology 73 (1992), pp. 153-169.

Louda et al., 1997 S. M. Louda, D. Kendall, J. Conner, and D. Simberloff, Ecological effects of an insect introduced for the biological control of weeds. Science 277 (1997), pp. 1088-1090.

Louda and Potvin, $1995 \rightarrow$ S. M. Louda and M. A. Potvin, Effect of inflorescence-feeding insects in the demography and lifetime fitness of a native plant. Ecology 76 (1995), pp. 229-245.

Louda et al., 2003a $>$ S. M. Louda, A. E. Arnett, T. A. Rand, and F. L. Russell, Invasiveness of some biological control insects and adequacy of their ecological risk assessment and regulation. Conservation Biology 17 (2003), pp. 73-82.

Louda et al., 2003b S. M. Louda, R. W. Pemberton, M. T. Johnson, and P. A. Follett, Nontarget effectsThe Achilles' heel of biological control? Retrospective analyses to reduce risk associated with biocontrol introductions. Annual Review of Entomology 48 (2003), pp. 365-396. 
Louda et al., 2003c $>$ S. M. Louda, T. A. Rand, A. E. Arnett, A. McClay, and A. K. McEachern. Evaluation of demographic risk to a threatened plant species, Cirsium pitcheri, from an invasive biocontrol weevil. Ecological Applications (in review; 2003).

Louda and Rodman, 1983 S. M. Louda and J. E. Rodman, Concentration of glucosinolates in relation to habitat and insect herbivory for the native crucifer Cardamine cordifolia. Biochemical Systematics and Ecology 11 (1983), pp. 199-208.

Louda et al., 1998 S. M. Louda, D. Simberloff, G. Boettner, J. Connor, D. Kendall, and A. E. Arnett, Insights from data on the nontarget effects of the flowerhead weevil. Biocontrol News and Information 26 (1998), pp. 70N-71N.

Loveless and Hamrick, 1988 M. D. Loveless and J. L. Hamrick, Genetic organization and evolutionary history in two North American species of Cirsium. Evolution 422 (1988), pp. 254-265.

Luu and Werner, 1996 B. Luu and F. Werner, Sterols that modify molting in insects. Pesticide Science 46 1 (1996), pp. 49-53.

Mabry and Gill, 1977 T. J. Mabry and J. E. Gill, Antifeedant sesquiterpene lactones in the Compositae. In: P. A. Hedin, ed., Host Plant Resistance to Pests, American Chemical Society, Washington, DC (1977).

Mabry et al., 1970 T. J. Mabry, K. R. Markham, and M. B. Thomas, The Systematic Identification of Flavonoids, Springer-Verlag, New York (1970).

Macedo and Langenheim, 1989 C. A. Macedo and J. H. Langenheim, A further investigation of leaf sesquiterpene variation in relation to herbivory in two Brazilian populations of Copaifera lansdorfii. Biochemical Systematics and Ecology 173 (1989), pp. 207-216.

Martinez-Vazquez et al., 1998 M. Martinez-Vazquez, A. T. O. Ramirez, A. L. Lastra, and R. Bye, A comparative study of the analgesic and anti-inflammatory activities of pectolinarin isolated from Cirsium subcoriaceum and linarin isolated from Buddleia cordata. Planta Medica 642 (1998), pp. 134-137.

Matsuda et al., $1982 \rightarrow$ K. Matsuda, S. Watanabe, and T. Sugiyama, Feeding response of Chyrsolina aurichalcea (Mannerheim) to polyacetylenes (Coleoptera,Chrysomelidae. Tohoku Journal of Agricultural Research 332 (1982), pp. 51-54 CA 98:140933.

Mauseth, 1988 J. D. Mauseth, Plant Anatomy, The Benjamin/Cummings Publishing Company, California (1988).

Mazur and Adlercreutz, 1998 W. Mazur and H. Adlercreutz, Natural and anthropogenic environmental estrogens, the scientific basis for risk assessment. Naturally occurring estrogens in food. Pure and Applied Chemistry 709 (1998), pp. 1759-1776.

McGowan and Wallace, 1972 S. G. McGowan and J. W. Wallace, Flavonoids and phenolic acids from Cirsium lanceolatum. Phytochemistry 11 (1972), pp. 1503-1504.

McLachlan et al., $1982 \rightarrow$ D. McLachlan, J. T. Arnason, B. J. R. Philogene, and D. Champagne, Anti-feedant activity of the polyacetylene, phenylheptatriyne (PHT), from the Asteraceae to Euxoa messoria (Lepidoptera, Noctuidae). Experientia 389 (1982), pp. 1061-1062.

Miyaichi et al., $1995>$ Y. Miyaichi, M. Matsuura, and T. Tomimori, Phenolic compound from the roots of Cirsium japonicum dc. Natural Medicines (Tokyo, Japan) 491 (1995), pp. 92-94 CA 123:193578 .

Miyazawa et al., 1998 M. Miyazawa, K. Hirota, M. Fukuyama, Y. Ishikawa, and H. Kameoka, Insecticidal lignans against Drosophila melanogaster from fruits of Schisandra chinensis. Natural Product Letters 123 (1998), pp. 175-180.

Miyazawa et al., 1994 M. Miyazawa, Y. Ishikawa, H. Kasahara, J. Yamanaka, and H. Kameoka, An insect growth inhibitory lignan from flower buds of Magnolia fargesii. Phytochemistry 353 (1994), pp. 611-613.

Montlor et al., $1990 \rightarrow$ C. B. Montlor, E. A. Bernays, and R. V. Barbehenn, Importance of quinolizidine alkaloids in the relationship between larvae of Uresiphita reversalis (Lepidoptera, Pyralidae) and host plant, Genista monspessulana. Journal of Chemical Ecology 166 (1990), pp. 1853-1865.

Morita et al., 1964 N. Morita, M. Fukuta, and M. Shimizu, Studies on the medicinal resources XXIII, Flavonoids of Cirsium plants (Compositae) in Japan. Components of the leaves of Cirsium microspicatum Nakai var. kiotense Kitam., C. dipsicolepis Matsum., C. brevicaule A. Gray, C. matsumurae Nakai, C. yakusimense Masamune, C. amplexifolium Kitam., C. spinosum Kitam., C. tanakae Matsum. subsp. aomorense Kitam. and C. arvense scop. var. setosum Ledeb. Yakugaku Zasshi 18 (1964), pp. 9-11.

Morita et al., $1965>$ N. Morita, M. Fukuta, and M. Shimizu, Studies on the medicinal resources XXIII, Flavonoids of Cirsium plants (Compositae) in Japan. Components of the leaves of Cirsium lucens Kitam., C. gyojanum Kitam., C. bitchuense Nakai and C. sieboldi Miq. Yakugaku Zasshi 191 (1965), pp. 8-10.

Morita and Lin, 1976 N. Morita and C. -N. Lin, Studies on the components of Formosan Cirsium species. Part IV. Components of Cirsium arisanense Kitamura and Cirsium ferum Kitamura. Tiawan Yao xue Zazhi 28 1-2 (1976), pp. 40-42. 
Morita et al., 1973 N. Morita, M. Shimizu, and M. Arisawa, Flavonoids of Cirsium. VI. Two new flavone glycosides from Cirsium lineare. Phytochemistry 122 (1973), pp. 421-423.

Nakaoki and Morita, $1959 \rightarrow$ T. Nakaoki and N. Morita, Studies on the medicinal resources XIII, Flavonoids of Cirsium plants (Compositae) in Japan. Components of the leaves of Cirsium microspicatum Nakai, C. otayae Kitamura, C. yoshizawae Koidz., C. japonicum DC., C. purpuratum Matusum. Yakugaku Zasshi 7910 (1959), pp. 1338-1340 CA 54:19378.

Nakaoki and Morita, 1960 T. Nakaoki and N. Morita, Studies on the medicinal resources XIV, Flavonoids of Cirsium plants (Compositae) in Japan. Components of the leaves of Cirsium kagamontanum Nakai, C. inundatum Makino, and C. matsumurae Nakai var. pubescens Kitamura. Yakugaku Zasshi 809 (1960), pp. 1296-1297 CA 55:15207.

National Invasive Species Council, 2001 National Invasive Species Council, 2001. National Invasive Species Management Plan (or) Meeting the Invasive Species Challenge. Washington, DC (2001). Online at http://www.invasivespecies.gov/council/nmp

Nawrot et al., 1983 J. Nawrot, Z. Smitalova, and M. Holub, Deterrent activity of sesquiterpene lactones form the Umbelliferae against storage pests. Biochemical Systematics and Ecology 113 (1983), pp. 243-245.

Negi et al., 1989 R. K. S. Negi, T. M. Fakhir, and T. R. Rajagopalan, A pyrrolizidine alkaloid from Cirsium wallichii DC. Indian Journal of Chemistry 28B (1989), pp. 524-525.

Nishida et al., $1990>$ R. Nishida, S. Ohsugi, and H. Fukami, Oviposition deterrent of a Rutaceae-feeding swallowtail butterfly, Papilio xuthus, from a non-host rutaceous plant, Orixa japonica. Agricultural and Biological Chemistry 54 (1990), pp. 1256-1270.

Nolasco et al., 1987 S. N. Nolasco, M. H. Bertoni, L. Malec, and Y. P. Cattaneo, Seeds of Onopordon acanthium L. (Scotch thistle), Carduus acanthoides L. (plumeless thistle) and Cirsium vulgare (Savi) Ten (bull thistle). Extracted crude oils and seed meals. Anales de la Asociacion Quimica Argentina 751 (1987), pp. 29-34 CA 107:132917.

OTA, 1995 Office of Technology Assessment. Biologically based technologies for pest control. US Government Printing Office (1995).

Ogurtsova and Syuzeva, 1974 L. N. Ogurtsova and Z. F. Syuzeva, Flavonoids of Cirsium heterophyllum. Khimiya Prirodnykh Soedinenii 101 (1974), p. 90 CA 81:60808.

Ohsugi et al., 1985 T. Ohsugi, R. Nishida, and H. Fukammi, Oviposition stimulants of Papilio xuthus, a cirtus-feeding swallowtail butterfly. Agricultural and Biological Chemistry 49 (1985), pp. 1897-1900.

Oksuz and Putun, 1983 - S. Oksuz and E. Putun, Guaianolides from Centaurea kotschyi. Phytochemistry 2211 (1983), pp. 2615-2616.

Palmisano and Fox, 1997 S. Palmisano and L. R. Fox, Effects of mammal and insect herbivory on population dynamics of a native California thistle, Cirsium occidentale. Ecologia 111 (1997), pp. 413-421.

Park et al., 1995a - J. -C. Park, J. -H. Lee, and J. -W. Choi, A flavone diglycoside from Cirsium japonicum var. ussuriense. Phytochemistry 391 (1995), pp. 261-262.

Park et al., 1995b - J. -C. Park, J. -H. Lee, and J. -W. Choi, Isolation and biological activity of flavone glycosides from the aerial part of Cirsium japonicum var. ussuriense in Korea. Han'guk Yongyang Siklyong Hakhoechi 246 (1995), pp. 906-910.

Picman, 1986 A. K. Picman, Biological activities of sesquiterpene lactones. Biochemical Systematics and Ecology 143 (1986), pp. 255-281.

Picman et al., 1978 A. K. Picman, R. H. Elliott, and G. H. N. Towers, Insect feeding deterrent property of alantolactone. Biochemical Systematics and Ecology 6 (1978), pp. 333-335.

Pimentel et al., 2000 D. Pimentel, L. Lach, R. Zuniga, and D. Morrison, Environmental and economic costs of nonindigenous species in the United States. BioScience 50 (2000), pp. 53-64.

Pliske et al., 1976 T. E. Pliske, J. A. Edgar, and C. C. J. Culvenor, The chemical basis of attraction of ithomiine butterflies to plants containing pyrrolizidine alkaloids. Journal of Chemical Ecology 23 (1976), pp. 255-262.

Prestwich, 1986 G. D. Prestwich, Fluorinated sterols, hormones, and pheromones, enzyme-targeted disruptants in insects. Pesticide Science 174 (1986), pp. 430-440.

Price, $1984 \longrightarrow$ P. W. Price, Insect Ecology. Wiley-Interscience (1984).

Ramasubramanian et al., 1988 A. Ramasubramanian, P. Ravi, and P. Ramesh, Synthesis of cirsimaritin (5,4'-Dihydroxy-6,7-dimethoxyflavone) by transacylation method. Indian Journal of Chemistry, Section B, Organic Including Medicinal 27 (1988), p. 182.

Rasulov et al., 1989 F. A. Rasulov, S. V. Serkerov, N. M. Ismailov, and E. N. Novruzov, Chemical investigation of Cirsium echinus. Izv Akad Nauk Az SSR, Izvestiya Akademii Nauk Azerbaidzhanskoi SSR, Seriya Biologicheskikh Nauk 6 (1989), pp. 14-16 CA 116:55515 . 
Rees, 1977 N. E. Rees, Impact of Rhinocyllus conicus on thistles in south western Montana. Environmental Entomology 6 (1977), pp. 839-842.

Rees, $1978 \longrightarrow$ N. E. Rees, Interactions of Rhinocyllus conicus and thistles in the Gallatin Valley. In: Biological control of thistles in the genus Carduus in the United States. A progress report, U. S. Department of Agriculture, Mississippi, USA (1978), pp. 31-38.

Rees and Harborne, $1985 \triangleright$ S. B. Rees and J. B. Harborne, The role of sesquiterpene lactones and phenolics in the chemical defense of the chicory plant. Phytochemistry 2410 (1985), pp. 2225-2231.

Rendyuk et al., 1977a $>$ T. D. Rendyuk, V. I. Glyzin, and A. I. Shreter, Phytochemical study of Cirsium setosum (Willd.). Acta Pharmaceutica Jugoslavica 273 (1977), pp. 135-138 CA 88:117796 .

Rendyuk et al., 1977b $>$ T. D. Rendyuk, A. I. Shreter, V. L. Shelyuto, and V. I. Glyzin, Flavonol glycoside of Cirsium arvense. Khimiya Prirodnykh Soedinenii 13 (1977), p. 282 CA 87:114617 .

Rodriguez et al., 1976 E. Rodriguez, G. H. N. Towers, and J. C. Mitchell, Biological activities of sesquiterpene lactones. Phytochemistry 15 (1976), pp. 1573-1580.

Roitberg and Isman, 1992 B. D. Roitberg and M. B. Isman, Insect Chemical Ecology, An Evolutionary Approach, Chapman \& Hall, New York (1992).

Rose et al., 1980 A. F. Rose, B. A. Butt and T. Jermy, Antifeedants for the Colorado potato beetle, Leptinotarsa decemlimeata. Part 2. Polyacetylenes from the rabbitbrush, Chrysothamnus nauseosus. Phytochemistry 194 (1980), pp. 563-566.

Rosenthal and Berenbaum, 1991 G. A. Rosenthal and M. R. Berenbaum, Herbivores, Their Interactions with Secondary Plant Metabolites, vols 1 and 2, Academic Press, San Diego (1991).

Rossiter et al., $1986 \rightarrow$ M. Rossiter, J. Gershenzon, and T. J. Mabry, Behavioral and growth responses of specialist herbivore, Homoesoma electellum, to major terpenoid of its host, Helianthus spp. Journal of Chemical Ecology 126 (1986), pp. 1505-1521.

Sawaguchi et al., $1994-$ K. Sawaguchi, K. Nakao, T. Shimamura, and K. Ohsawa, A new antimicrobial and antioxidative component of extracts from the rhizomes of Cirsium brevicaule A. Gray var. irumtiense Kitam. Japan Bokin Bobai 225 (1994), pp. 271-275 CA 121:251185.

Seaman, $1982 \longrightarrow$ F. C. Seaman, Sesquiterpene lactones as taxonomic characters in the Asteraceae. The Botanical Review 482 (1982), pp. 123-162.

Shanks and Doss, $1987 \rightarrow$ C. H. Shanks and R. P. Doss, Feeding responses by adults of five species of weevils (Coleoptera, Curculionidae) to sucrose and sterols. Annals of the Entomological Society of America 801 (1987), pp. 41-46.

Shelyuto et al., $1975-$ V. L. Shelyuto, V. N. Al'khimovich and E. P. Kruglova, Flavonoids of common thistle flowers. Fitokhim Izuch Flory BSSR Biofarm Issled Lek Prep (1975), pp. 95-96 CA 88:186100 .

Shelyuto et al., $1970 \triangleright$ V. L. Shelyuto, V. I. Glyzin, and A. I. Ban'kovskii, Flavonoids from Cirsium arvense. Khimiya Prirodnykh Soedinenii 63 (1970), pp. 365-366.

Shelyuto et al., $1971-$ V. L. Shelyuto, V. I. Glyzin, A. I. Ban'kovskii, and N. T. Bubon, Flavonoid glycosides of Cirsium oleraceum. Khimiya Prirodnykh Soedinenii 73 (1971), pp. 372-373 CA 75:115878 .

Shelyuto et al., 1972a V V. L. Shelyuto, V. I. Glyzin, and N. T. Bubon, 3-O-Methylkaempferol from Cirsium arvense flowers. Khimiya Prirodnykh Soedinenii 81 (1972), pp. 118-119 CA 77:85580 .

Shelyuto et al., 1972b V V. L. Shelyuto, V. I. Glyzin, and N. T. Bubon, Flavonoids of Cirsium palustre. Khimiya Prirodnykh Soedinenii 2 (1972), pp. 241-242 CA 77:58855.

Shelyuto et al., $1978 \rightarrow$ V. L. Shelyuto, V. I. Glyzin, G. N. Yurchenko, and L. P. Smirnova, Flavonoids from Cirsium oleraceum flowers. Khimiya Prirodnykh Soedinenii 3 (1978), pp. 400-402 CA 89: 126161.

Shen and Mu, 1990 Y. Shen and Q. Mu, New furans from Cirsium chlorolepis. Planta Medica 56 (1990), pp. 472-474.

Simberloff and Stiling, 1996 D. Simberloff and P. Stiling, How risky is biological control?. Ecology 77 (1996), pp. 1965-1974.

Simberloff, 1997 D. Simberloff, The biology of invasions. In: D. Simberloff, D. C. Schmitz and T. C. Brown, eds., Strangers in Paradise, Impact and Management of Nonindigenous Species in Florida, Island Press (1997), pp. 3-17.

Simmonds, 2001 M. J. Simmonds, Importance of flavonoids in insect-plant interactions, feeding and oviposition. Phytochemistry 56 (2001), pp. 245-252.

Simmonds and Grayer, 1999 M. J. Simmonds and R. J. Grayer, Drug discovery and development. In: N. J. Walton and D. E. Brown, eds., Chemicals From Plants, Perspectives on Plant Secondary Products, Imperial College Press, London (1999), pp. 215-249.

Singer, 1971 M. C. Singer, Evolution of food-plant preference in the butterfly Euphydryas editha. Evolution 25 (1971), pp. 383-389.

Spencer, 1988 K. C. Spencer, Chemical Mediation of Coevolution, Academic Press Inc, San Diego (1988). 
Statti et al., 1997 G. Statti, F. Menichini and F. D. Monache, Constituents of Cirsium vallis-demonii. Fitoterapia 685 (1997), p. 472.

Stevens et al., $1990 \checkmark$ K. L. Stevens, S. C. Witt and C. E. Turner, Polyacetylenes in related thistles of the subtribes Centaureinae and Carduinae. Biochemical Systematics and Ecology 184 (1990), pp. 229-232.

Stiling and Simberloff, $1999>$ P. Stiling and D. Simberloff, The frequency and strength of non-target effects of invertebrate biological control agents. In: P. A. Follett and J. J. Duan, eds., Nontarget Effects of Biological Control, Kluwer Academic Publishers (1999), pp. 31-43.

Strack, 1997 D. Strack, Phenolic metabolism. In: P. M. Dey and J. B. Harborne, eds., Plant Biochemistry, Academic Press, San Diego (1997), pp. 387-416.

Strong and Pemberton, $2000 \rightarrow$ D. R. Strong and R. W. Pemberton, Biological control of invading species - Risk and reform. Science 288 (2000), pp. 169-179.

Svoboda, 1992 J. A. Svoboda, Inhibition of sterol metabolism in insects and nematodes. In: ASC Symposium Series, Agriculture Research Service: Regulation of Isopentenoid Metabolism, vol. 497 (1992), pp. 205-218.

Svoboda et al., 1994 J. A. Svoboda, M. F. Feldlaufer, and G. F. Weirich, Evolutionary aspects of steroid utilization in insects. In: ASC Symposium Series, Agriculture Research Service: Isopentoenoids and Other Natural Products (1994), pp. 126-139.

Svoboda and Lusby, 1994 J. A. Svoboda and W. R. Lusby, Variability of sterol utilization in storedproducts insects. Experientia 501 (1994), pp. 72-74.

Svoboda et al., 1991 J. A. Svoboda, G. F. Weirich, and M. F. Feldlaufer, Recent advances in insect steroid biochemistry. In: G. W. Patterson and N. W. David, eds., Physiological Biochemistry of Sterols, AOCS, Champaigne, Illinois (1991).

Syrchina et al., 1999 A. I. Syrchina, Y. A. Kostyro, I. A. Ushakov, and A. A. Semenov, Flavonoids of Cirsium setosum (Willd) Bess. Rastiel'nye Resursy 354 (1999), pp. 38-40 CA 113:14585 .

Syrchina et al., $1998 \rightarrow$ A. I. Syrchina, A. A. Semenov, and S. V. Sinchenko, Investigation of chemical composition of Cirsium setosum (Willd) Bess. Rastiel'nye Resursy 342 (1998), pp. 47-49 CA 130:63631 .

Syrchina et al., 2000 A. I. Syrchina, A. L. Vereschagin, Y. A. Kostyro, A. G. Gorshkov, and A. A. Semenov, Contents of some flavonoid compounds and syringin in different parts of Cirsium setosum (Willd) Bess. Rastiel'nye Resursy 362 (2000), pp. 73-79 CA 133:307562 .

Takaishi et al., $1990 \gg$ Y. Takaishi, T. Okuyama, A. Masuda, K. Nakano, K. Murakami, and T. Tomimatsu, Acetylenes from Cirsium japonicum. Phytochemistry 2912 (1990), pp. 3849-3852.

Takaishi et al., 1991a $>$ Y. Takaishi, T. Okuyama, K. Nakano, K. Murakami, and T. Tomimatsu, Absolute configuration of a triolacetylene from Cirsium japonicum. Phytochemistry 307 (1991), pp. 2321-2324.

Takaishi et al., 1991b $>$ Y. Takaishi, T. Okuyama, K. Nakano, K. Murakami, T. Tomimatsu, and J. Yamahara, Polyolefinic compounds from Cirsium nipponicum roots. Phytochemistry 305 (1991), pp. 1539-1542.

Takano and Kawaminami, 1988 S. Takano and S. Kawaminami, Cyperenyl acetate and cyperenal from Cirsium dipscolepis. Phytochemistry 294 (1988), pp. 1197-1199.

Tarle et al., 1984 D. Tarle, J. Petricic, and M. Kupinic, Cirsium oleraceum (L.) Scop. Chemical and antimicrobial investigation. Farm Glas 40 11-12 (1984), pp. 363-367 CA 102:154660 .

Thompson, 2000 L. U. Thompson, Lignans and isoflavones. Carcinog Anticarcinog Factors in Food (2000), pp. 348-364.

Towers et al., 1984 G. H. N. Towers, J. T. Arnason, C. K. Wat, and J. D. H. Lambert, Controlling pests using a naturally occurring conjugated polyacetylene. Canadian Patents 1172460 (1984). CA 102:57830.

Tulloch and Hoffman, 1982 A. P. Tulloch and L. L. Hoffman, Epicuticular wax of Cirsium arvense. Phytochemistry 217 (1982), pp. 1639-1642.

Turner et al., 1987 C. E. Turner, R. W. Pemberton, and S. S. Rosenthal, Host utilization of native Cirsium thistles (Asteraceae) by the introduced weevil Rhinocyllus conicus (Coleoptera, Curculionidae) in California. Environmental Entomology 16 (1987), pp. 111-115.

Ulubelen and Oksuz, 1982 A. Ulubelen and S. Oksuz, Cytotoxic flavones from Centaurea urvillei. Journal of Natural Products (Lloydia) 453 (1982), p. 373.

USDA Plant Database, 2002 United States Department of Agriculture NRCS. USDA Plants Database. 2002. Online at http:// plants.usda.gov/

Vitousek et al., 1997 P. M. Vitousek, H. A. Mooney, J. Lubchenco, and J. M. Melillo, Human domination of Earth's ecosystems. Science 277 (1997), pp. 494-499.

Wagner, 1977 H. Wagner, Cynareae-chemical review. In: V. H. Heywood, J. B. Harborne and B. L. Turner, eds., The Biology and Chemistry of the Compositae, Academic Press, London (1977), pp. 1018-1038. 
Wallace, 1974 J. W. Wallace, Tricin-5-O-glucoside and other flavonoids of Cirsium arvense. Phytochemistry 13 (1974), pp. 2320-2321.

Wallace and Bohm, $1971 \rightarrow$ J. W. Wallace and B. A. Bohm, Cirsimaritin-4'-O-rutinoside, a new flavone glycoside from Cirsium brevistylum. Phytochemistry 10 (1971), pp. 452-454.

Walton and Brown, 1999 N. J. Walton and D. E. Brown, Chemicals from Plants, Perspectives on Plant Secondary Products, Imperial College Press, London (1999).

Wan et al., 2000 S. Wan, H. Xu, S. Zhao, Z. Sheng, and Z. Liu, Phototoxicity of synthetic polyacetylenes against mosquito larvae (Culex quinquefasciatus). Kunchong Xuebao (South China Agricultural University) 433 (2000), pp. 264-270.

Wang et al., $1990 \triangleright$ Y. Wang, M. Toyota, F. Krause, M. Hamburger, and K. Hostettman, Polyacetylenes from Artemisia borealis and their biological activities. Phytochemistry 2910 (1990), pp. 3101-3105.

Wat et al., 1981 C. K. Wat, S. K. Prasad, E. A. Graham, S. Partington, T. Arnason, G. H. N. Towers, and J. Lam, Photosensitization of invertabrates by natural polyacetylenes. Biochemical Systematics and Ecology 91 (1981), pp. 59-62.

Whitehead et al., 1982 D. C. Whitehead, H. Dibb, and R. D. Hartley, Phenolic compounds in soil as influenced by the growth of different plant species. Journal of Applied Ecology 19 (1982), pp. 579-588.

Williamson et al., $1999>$ G. Williamson, M. J. C. Rhodes, and A. J. Parr, Disease prevention and plant dietary substances. In: N. J. Walton and D. E. Brown, eds., Chemicals from Plants, Perspectives on Plant Secondary Products, Imperial College Press, London (1999), pp. 251-276.

Wink, 1986 M. Wink, Storage of quinolizidine alkaloids in epidermal tissues. Zeitschrift fuer Naturfroschung 41C (1986), pp. 375-380 CA 105:39369 .

Wink, 1997 M. Wink, Special nitrogen metabolism. In: P. M. Dey and J. B. Harborne, eds., Plant Biochemistry, Academic Press, San Diego (1997), pp. 439-486.

Woodhead and Cooper-Driver, 1979 S. Woodhead and G. Cooper-Driver, Phenolic acids and resistance to insect attack in Sorghum bicolor. Biochemical Systematics and Ecology 7 (1979), pp. 309-310.

Woodhead et al., $1980 \triangleright$ S. Woodhead, D. E. Padgham, and E. A. Bernays, Insect feeding on different sorghum cultivars in relation to cyanide and phenolic acid content. Annals of Applied Biology 95 (1980), pp. 151-157.

Wu et al., 1981 T. S. Wu, C. S. Kuoh, and S. I. Jen, Constituents of Formosan folk medicine. VIII. Flavonoids of the leaves of Cirsium albescens, C. japonicum var. australe, C. kawakamii f. variegatum and C. hosogawa. Taiwan Yaoxue Zazhi 322 (1981), pp. 88-90 CA 96:31651.

Yano, 1977 K. Yano, Hydrocarbons from Cirsium japonicum. Phytochemistry 16 (1977), pp. 263-264.

Yano, 1980 K. Yano, A new acetylenic alcohol from Cirsium japonicum. Phytochemistry 19 (1980), pp. 1864-1866.

Youssef and Frahm, $1994 \rightarrow$ D. Youssef and A. W. Frahm, Constituents of the Egyptian Centaurea scoparia; II. Guaianolides of the aerial parts. Planta Medica 60 (1994), pp. 572-575.

Yun and Chang, 1978 H. S. Yun and I. M. Chang, Separation and identification of cirsimarin from Cirsium pendulum Fisch. Saengyak Hakhoe Chi 93 (1978), pp. 145-147 CA 01:189826.

Zielske et al., 1972 A. G. Zielske, J. N. Simons, and R. M. Silverstein, A flavone feeding stimulant in alligatorweed. Phytochemistry 11 (1972), pp. 393-396.

Zwölfer, 1965 H. Zwölfer, Preliminary list of phytophagous insects attacking wild Cynareae (Compositae) in Europe. Commonwealth Institute of Biological Control Technical Bulletin 6 (1965), pp. 81-154.

Zwölfer and Harris, $1984 \longrightarrow \mathrm{H}$. Zwölfer and P. Harris, Biology and host specificity of Rhinocyllus conicus (Froel.) (Col., Curculionidae), a successful agent for biocontrol of the thistle, Carduus nutans L. Zeitschrift Fur Angewandte Entomologia 97 (1984), pp. 36-62.

Zwölfer and Preiss, $1983 \rightarrow$ H. Zwölfer and M. Preiss, Host selection and oviposition behavior in west European ecotypes of Rhinocyllus conicus Froel. (Col., Curculionidae). Zeitschrift fur Angenrandte Entomologia 95 (1983), pp. 113-122. 